\title{
Siamopsis gen. nov. and five new species of the subfamily Cypridopsinae Kaufmann, 1900 (Crustacea: Ostracoda) from Thailand
}

\author{
Sukonthip SAVATENALINTON \\ Department of Biology, Plant and Invertebrate Taxonomy and its Applications Research Unit, Faculty \\ of Science, Mahasarakham University, Maha Sarakham 44150, Thailand. \\ Email: sukonthip.s@msu.ac.th \\ urn:1sid:zoobank.org:author:254994A1-C8E1-4242-ADF8-184661366B2D
}

\begin{abstract}
Siamopsis gen. nov., described here, belongs to a group of genera with the right valve overlapping the left valve in the subfamily Cypridopsinae Kaufmann, 1900 of the family Cyprididae Baird, 1845. The distinguishing characters of the new genus are in the morphology of its valves and soft parts. The postero-dorsal margin of the internal left valve is plate-like protruded. The morphology of this plate varies in different species, e.g., some species bear a tooth-like tubercle on the plate. The posterior margin of the right valve is recurved inwardly at ca mid-height, resulting in the occurrence of a lobe-like expansion that can clearly be seen in the dorsal and caudal views of the carapace. In addition, the other diagnostic soft part features of the new genus are the cylindrical caudal ramus, the presence of two t-setae on the female $\mathrm{A} 2$ penultimate segment, the very elongated terminal segment of the $\mathrm{Mx} 1$ palp, the morphology of the two large bristles (tooth bristles) of the Mx1 third endite (one smooth, one serrated) and the absence of d-seta on T1. In the present paper, five new species are described under this new genus: Siamopsis renateae gen. et sp. nov., S. suttajiti gen. et sp. nov., S. conspecta gen. et sp. nov., S. khoratensis gen. et sp. nov. and Siamopsis planitia gen. et sp. nov. A key to the species of Siamopsis gen. nov. is also provided.
\end{abstract}

Keywords. Cypridopsinae, biodiversity, taxonomy, new species, Thailand.

Savatenalinton S. 2017. Siamopsis gen. nov. and five new species of the subfamily Cypridopsinae Kaufmann, 1900 (Crustacea: Ostracoda) from Thailand. European Journal of Taxonomy 384: 1-39. https://doi.org/ejt.2017.384

\section{Introduction}

The subfamily Cypridopsinae Kaufmann, 1900, with Cypridopsis Brady, 1867 as type genus, is characterized by a reduced caudal ramus that forms flagellum-like structures. About 204 species in 17 genera of subfamily Cypridopsinae have so far been recognized worldwide (Martens \& Savatenalinton 2011; Higuti \& Martens 2012). The subfamily contains six monospecific genera: Austrocypridopsis McKenzie, 1982, Bryocypris Røen, 1956, Cabelocypridopsis Higuti \& Martens, 2012, Klieopsis Martens et al., 1991, Thermopsis Külköylüoğlu et al., 2003 and Tungucypridopsis Victor \& Fernando, 1983. Four of those genera, together with three multispecific others (Martenscypridopsis Karanovic, 
2000, Pseudocypridopsis Karanovic, 1999 and Tanganyikacypridopsis Martens, 1985), are endemic to specific zoogeographical regions. The most diverse and widely distributed genus is Cypridopsis, which contains 77 species occurring in all eight zoogeographical regions, namely the Antarctic, Afrotropical, Australasian, Nearctic, Neotropical, Oriental, Palaearctic and Pacific regions and the Oceanic Islands (Martens \& Savatenalinton 2011). In Southeast Asia, only six species of this subfamily, belonging to two genera, have been reported: Cypridopsis exigua G.O. Sars, 1903, C. adusta G.O. Sars, 1903, C. dubia G.O. Sars, 1903, Plesiocypridopsis albida (Vávra, 1897), P. arsenia (Tressler, 1937) and P. cf. newtoni (Brady \& Robertson, 1870) (Sars 1903; Tressler 1937; Hartmann 1964; Victor \& Fernando 1981). There is only one identified cypridopsine species, Cypridopsis vidua (Müller, 1776), known from Thailand (Savatenalinton et al. 2008; Savatenalinton \& Martens 2009, 2010; Savatenalinton \& Suttajit 2016). However, recently published studies of non-marine ostracods in Thailand have increased the number of new species and genera in the area (Savatenalinton 2015, 2017, Savatenalinton \& Suttajit 2016). In the present contribution, one new genus and five new species of this subfamily are described from Thailand. The remaining cypridopsine taxa will be presented elsewhere.

\section{Material and methods}

Samples were collected with a hand net (mesh size $150 \mu \mathrm{m}$ ), preserved in 70\% ethanol and sorted using an Olympus SZ-PT stereo-microscope. Soft parts were dissected in glycerine and sealed on glass slides. Valves were stored dry in micropalaeontological slides. Drawings of soft parts were made with the aid of a camera lucida. Carapaces and valves were observed and illustrated using a scanning electron microscopy (JEOL JSM6460LV at the Faculty of Science, MSU and Philips XL30 SEM at RBINS). The chaetotaxy of the limbs follows the model proposed by Broodbakker \& Danielopol (1982), revised for the A2 by Martens (1987) and for the thoracopods by Meisch (2000). Type material of all species is deposited in the Natural History Museum, MSU (Maha Sarakham, Thailand).

\section{Abbreviation used in text and figures}

Institutional acronyms:

$\begin{aligned} \text { MSU }= & \text { Mahasarakham University, Maha Sarakham, Thailand } \\ \text { MSU-ZOC = } & \text { Ostracod Collection of the Natural History Museum, Mahasarakham University, } \\ & \text { Maha Sarakham, Thailand } \\ \text { RBINS }= & \text { Royal Belgian Institute of Natural Sciences, Brussels }\end{aligned}$

The following abbreviations are used for valves and carapace:

$\mathrm{CpC}=$ carapace in caudal view

$\mathrm{CpD}=$ carapace in dorsal view

$\mathrm{CpL}=$ carapace in left lateral view

$\mathrm{CpR}=$ carapace in right lateral view

$\mathrm{H}=$ height of valves

$\mathrm{L} \quad=$ length of valves

$\mathrm{LV}=$ left valve

$\mathrm{LVe}=$ left valve external view

$\mathrm{LVi}=$ left valve internal view

$\mathrm{RV}=$ right valve

$\mathrm{RVe}=$ right valve external view

$\mathrm{RVi}=$ right valve internal view

$\mathrm{W}=$ width of carapace 
The following abbreviations are used for limbs:

$\mathrm{A} 1=$ first antenna

$\mathrm{A} 2=$ second antenna

$\mathrm{CR}=$ caudal ramus

$\mathrm{Md}=$ mandibula

$\mathrm{Mx} 1=$ maxillula

$\mathrm{T} 1=$ first thoracopod (maxilliped)

$\mathrm{T} 2=$ second thoracopod (walking leg)

$\mathrm{T} 3=$ third thoracopod (cleaning leg)

\section{Results}

\section{Taxonomic descriptions}

Class Ostracoda Latreille, 1802

Subclass Podocopa G.O. Sars, 1866

Order Podocopida G.O. Sars, 1866

Suborder Cypridocopina Jones, 1901

Superfamily Cypridoidea Baird, 1845

Family Cyprididae Baird, 1845

Subfamily Cypridopsinae Kaufmann, 1900

Siamopsis gen. nov.

urn:1sid:zoobank.org:act:F4387DB9-8A9E-44FB-8B7B-9F07A89C26DE

\section{Type species}

Siamopsis renateae gen. et sp. nov. (here designated)

\section{Diagnosis}

RV overlapping LV anteriorly, ventrally and posteriorly. LV in internal view with postero-dorsal plate. Posterior margin of RV recurved inwardly. Wouters organ on A1 present, aesthetasc ya long. Terminal segment of Mx1 palp cylindrical, very elongated (length $>2 \times$ width). A2 with well developed claws, long natatory setae, with two t-setae in females. T1 with a-setae ( $b, c$ and $d$ setae absent). T2 with $\mathrm{d} 2$ seta (d1 seta absent). CR reduced, flagellum-like, cylindrical in shape.

\section{Etymology}

The genus is named after the country "Siam", the former name of Thailand, where the new taxa were discovered. The name is combined with the suffix of the existing generic name Cypridopsis.

\section{Differential diagnosis}

Siamopsis gen. nov. can be distinguished from other genera of the subfamily Cypridopsinae by the presence of a postero-dorsal internal plate of the LV and the morphology of the posterior inner valve margin of the RV, which is recurved inwardly. Additionally, it differs from its closest genus, Plesiocypridopsis Rome, 1965, by the presence of the A1 Wouters organ, the two t-setae of the female A2 (there are four t-setae in Plesiocypridopsis) and the morphology of the two large bristles (teeth bristles) on the Mx1 third endite, of which one bristle is smooth while the other one is serrated (both setae are serrated in Plesiocypridopsis). 


\section{Species included}

Siamopsis renateae gen. et sp. nov., S. suttajiti gen. et sp. nov., S. conspecta gen. et sp. nov., S. khoratensis gen. et sp. nov., S. planitia gen. et sp. nov.

\section{Distribution}

Thailand (present study).

\section{Remarks}

The postero-dorsal plate of the internal LV bears tooth- or teeth-like tubercle(s) in several species of Siamopsis gen. nov. The position of these tubercles can vary from species to species, being on, for example, the margin or in the middle of the plate. The degree of the inward curve on the RV posterior margin is different among species. Therefore, these aspects are used as taxonomic characters for identification.

\section{Siamopsis renateae gen. et sp. nov. urn:lsid:zoobank.org:act:1C17AC72-8E9E-4D70-B202-3A14626F2A74}

Figs $1-4,19$ A, 20

\section{Diagnosis}

Carapace in lateral view subtriangular, dorsal margin strongly arched, slightly angulated at posterodorsal part, greatest height situated in front of mid-length, RV overlapping LV anteriorly, ventrally, posteriorly. Valve surface set with long (rim-pore) setae and shallow pits dispersedly. Carapace in dorsal view tumid with even lateral margins. LV in internal view, with large marginal zone anteriorly, both anterior and posterior valve margins subequally rounded, postero-dorsal plate broad with two small marginal teeth-like tubercles, inner lamella calcified, with inner lists anteriorly and posteriorly. RV in internal view with large marginal zone anteriorly, inner lamella with inner lists anteriorly and posteriorly, without small tubercle-like structures under posterior inner list. Mx1 third endite with two (one smooth, one serrated) large bristles, terminal segment of Mx1 palp cylindrical, very elongated. CR of cylindrical shape, with flagellum-like seta.

\section{Etymology}

This species is named after Dr. Renate Matzke-Karasz (Munich University, Germany) in appreciation of her outstanding work on ostracods and also for a long friendship.

\section{Material examined}

\section{Holotype}

THAILAND: $q$, with soft parts dissected in glycerine on a sealed glass slide and valves stored dry in a micropalaeontological slide (MSU-ZOC.190).

\section{Paratypes}

THAILAND: 1 , same data as for holotype (MSU-ZOC.191-192); 2 q $q$ carapaces, stored dry in micropalaeontological slides (MSU-ZOC.193-194); ca 5 q $ᄋ$ in $70 \% \mathrm{EtOH}$.

\section{Other material}

THAILAND: Nakhon Ratchasima Province: Sikhiu District, Sub Pradu Reservoir (locality 2 in Fig. 20), $14^{\circ} 57^{\prime} 57^{\prime \prime} \mathrm{N}, 102^{\circ} 05^{\prime} 03^{\prime \prime}$ E, 6 Feb. 2006. Accompanying ostracod fauna: Potamocypris sp., Physocypria sp. 2, Physocypria sp. 3, Limnocythere stationis Vavra, 1891, Strandesia (juveniles). - Phayao Province: Mae Jai District, Mae Peum Reservoir (locality 3 in Fig. 20), 19²1'29" N, 9951'45" E, 7 Oct. 2007. 


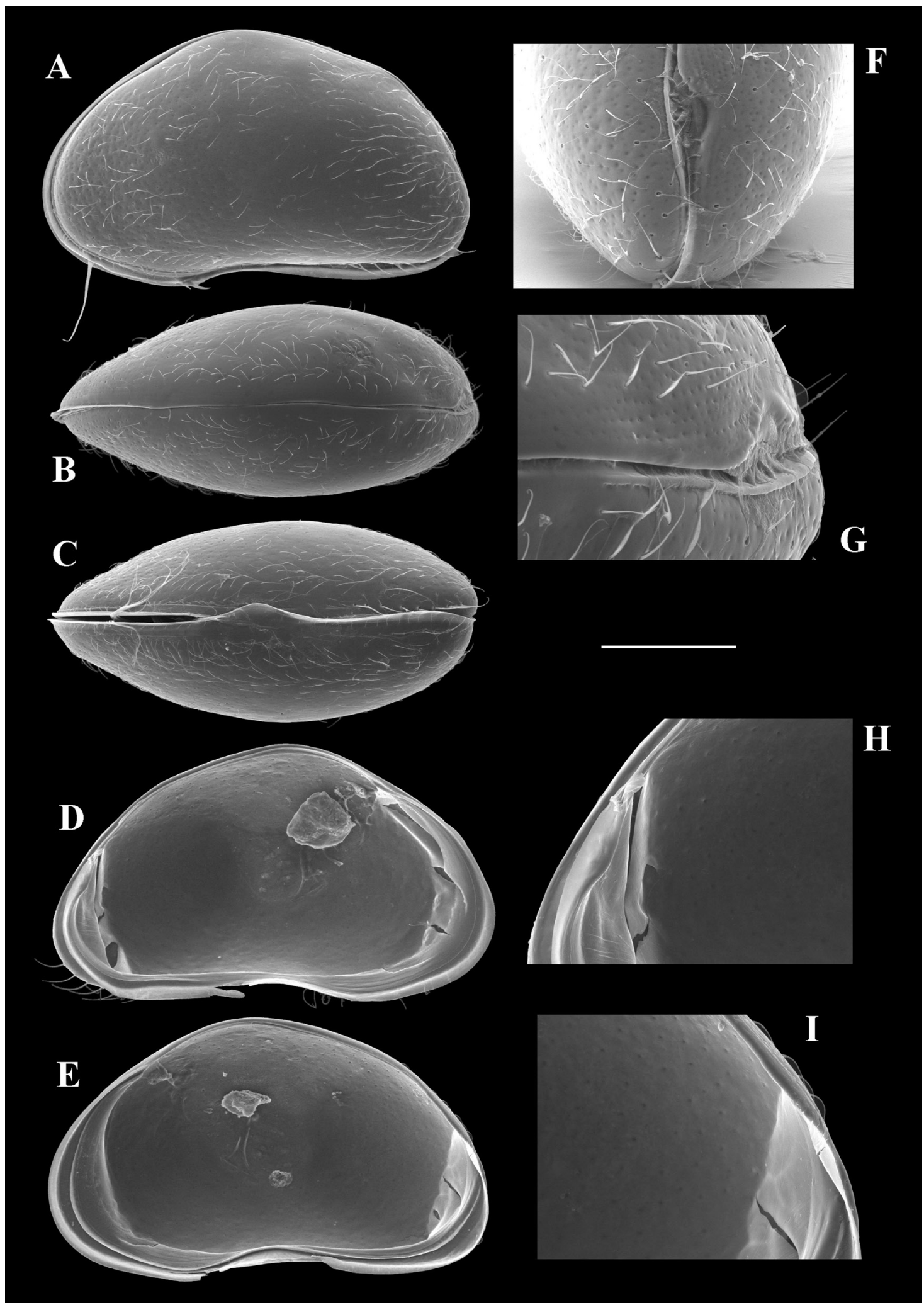

Fig. 1. Siamopsis renateae gen. et sp. nov., q. A. CpL (MSU-ZOC.193). B. CpD (MSU-ZOC.194). C. CpV (idem). D. LVi (MSU-ZOC.190). E. RVi (idem). F. CpC (MSU-ZOC.194). G. Posterior end of CpD (idem). H. Postero-dorsal part of LVi (MSU-ZOC.190). I. Postero-dorsal part of RVi (idem). Scale bar: A-E $=200 \mu \mathrm{m} ; \mathrm{F}=43 \mu \mathrm{m} ; \mathrm{G}=135 \mu \mathrm{m} ; \mathrm{H}-\mathrm{I}=84 \mu \mathrm{m}$. 
Accompanying ostracod fauna: Hemicypris exigua Broodbakker, 1983, Stenocypris malayica Victor \& Fernando, 1981, Bradleystrandesia weberi (Moniez, 1892), Bradleytriebella lineata (Victor \& Fernando, 1981), Pseudostrandesia mamarilorum (Victor \& Fernando, 1981), Strandesia kraepelini (Müller, 1906), S. perakensis Victor \& Fernando, 1981, Tanycypris siamensis Savatenalinton \& Martens, 2009, Cypretta sp. and Physocypria sp. 3. - Chiang Rai Province: Chiang Saen District, rice field (locality 4 in Fig. 20), 20 ${ }^{\circ} 16^{\prime} 10^{\prime \prime} \mathrm{N}, 100^{\circ} 03^{\prime} 09^{\prime \prime}$ E, 25 Sep. 2005. Accompanying ostracod fauna: Vestalenula boteai (Danielopol, 1970) and Strandesia (juveniles). - Phitsanulok Province: Wat Boht District, roadside canal (locality 5 in Fig. 20), 16 $09^{\prime} 52^{\prime \prime}$ N, 100 $19^{\prime} 47^{\prime \prime}$ E, 12 Feb. 2006. Accompanying ostracod fauna: Chrissia humilis (Klie, 1932), Hemicypris exigua, Pseudostrandesia mamarilorum, Pseudocypretta maculata Klie, 1932, Physocypria sp. 1, Physocypria sp. 2, Ilyocypris sp. and Limnocythere stationis Vavra, 1891. - Phetchabun Province: Muang District, Nong Naree (swamp) (locality 6 in Fig. 20), $16^{\circ} 26^{\prime 2} 24^{\prime \prime}$ N, 101 ${ }^{\circ} 08^{\prime 2} 29^{\prime \prime}$ E, 9 Oct. 2007. Accompanying ostracod fauna: Bradleycypris vittata (Sars, 1903), Bradleystrandesia weberi, Strandesia kraepelini, Cypretta sp. 3, Potamocypris sp., Siamopsis planitia gen. et sp. nov., Physocypria sp. 2 and Physocypria sp. 3. - Chaiyaphum Province: Konsarn District, rice field (locality 7 in Fig. 20), 16 23'3" N, 101 ${ }^{\circ} 58^{\prime} 47^{\prime \prime}$ E, 9 Oct. 2007. Accompanying ostracod fauna: Pseudostrandesia calapanensis (Tressler, 1937), P. mamarilorum, Strandesia sexpunctata Klie, 1932, Cypretta sp. 3 and Physocypria sp. 1. - Chaiyaphum Province: pond (locality 8 in Fig. 20), $16^{\circ} 23^{\prime} 3^{\prime \prime}$ N, 101 ${ }^{\circ} 58^{\prime} 47^{\prime \prime}$ E, 9 Oct. 2007. Accompanying ostracod fauna: Cypris subglobosa Sowerby, 1840, Strandesia sexpunctata, Cypretta sp. 3 and Physocypria sp. 1.

\section{Type locality}

THAILAND: Nakhon Ratchasima Province, Muang District, irrigation ditch (locality 1 in Fig. 20), $14^{\circ} 43^{\prime} 46^{\prime \prime}$ N, 104³3'56" E, 5 Oct. 2010. Accompanying ostracod fauna: Cypris subglobosa Sowerby, 1840, Cyprinotus uenoi Brehm, 1936, Stenocypris cf. orientalis Victor \& Fernando, 1981, Siamopsis khoratensis gen. et sp. nov., $S$. conspecta gen. et sp. nov. and $S$. planitia gen. et sp. nov.

\section{Differential diagnosis}

Siamopsis renateae gen. et sp. nov. differs from the other species of the new genus by the presence of a strongly arched dorsal margin, resulting in the subtriangular carapace in lateral view (elongated shape in other species), the postero-dorsal plate on LV having two small, teeth-like tubercles on the inner border and the absence of tiny tubercle-like structures under the RV posterior inner list. Additionally, the ya and accompanying seta on A1 are subequal in length in $S$. renateae gen. et sp. nov. while the length of the accompanying seta is $\mathrm{ca}^{2} / 3$ that of ya in other species of Siamopsis gen. nov. Compared to the $\mathrm{g}$-seta on $\mathrm{T} 2$, the length of the seta located next to the $\mathrm{g}$-seta is short (ca $1 / 3$ of g-seta) in $S$. renateae gen. et sp. nov. The length of this seta is ca half of that of the g-seta in other species of Siamopsis gen. nov.

Measurements (mean, in $\mu \mathrm{m}$ )

$\mathrm{LV}(\mathrm{n}=2), \mathrm{L}=653, \mathrm{H}=393 ; \mathrm{RV}(\mathrm{n}=2), \mathrm{L}=649, \mathrm{H}=401$; carapace $(\mathrm{n}=2), \mathrm{L}=631, \mathrm{~W}=302$.

\section{Description}

\section{Female}

CARAPACE. In lateral view (Fig. 1A) subtriangular, anterior margin rounded, posterior margin narrower rounded, dorsal margin strongly arched and slightly angulated at postero-dorsal part, greatest height situated in front of mid-length, RV overlapping LV anteriorly, ventrally and posteriorly, valve surface set with long setae, long rim-pore setae and shallow pits dispersedly. Carapace in dorsal view (Fig. 1B, G) tumid, with evenly curved lateral margins, greatest width situated at mid-length, posterior extremity round, anterior extremity more pointed. 
VALVES. LV in internal view (Fig. 1D, H) with large marginal zone anteriorly, both valve margins subequally rounded, ventral margin sinuous at mid-length, postero-dorsal plate broad, with two small marginal teeth-like tubercles, calcified inner lamella with inner lists anteriorly and posteriorly. RV in internal view (Fig. 1E, I) with large marginal zone anteriorly, ventral margin sinuous at mid-length, inner lamella calcified with inner lists anteriorly and posteriorly.

A1 (Fig. 2A). Seven-segmented, first segment with large proximal Wouters organ, one long dorsosubapical seta (reaching beyond tip of next segment) and two long ventro-apical setae. Second segment slightly wider than long, with one long dorso-apical seta (reaching tip of next segment) and Rome organ. Third segment bearing two setae: one long dorso-apical (reaching tip of penultimate segment) and one short ventro-apical. Fourth segment with two long dorsal setae and two short ventral setae (both reaching beyond half of fifth segment). Fifth segment dorsally with two long setae, ventrally with two (one long, one short) setae, short one reaching beyond end of next segment. Penultimate segment with four long apical setae. Terminal segment with three (two long, one short) apical setae and long aesthetasc ya, length of short seta ca $1 / 3$ of aesthetasc ya.

A2 (Fig. 2B). Exopodite with three (one long, two short) setae, long one reaching beyond tip of first endopodal segment. First endopodal segment with five long (reaching far beyond tips of terminal claws) and one short natatory seta, length of shortest seta ca half that of penultimate segment, aesthetasc Y long, ventro-apical seta long, extending beyond tip of terminal segment. Penultimate segment undivided, distally with three serrated claws (G1, G2, G3), G2 shorter (length of G2 ca 3/4 that of G1), aesthetasc y2 long (ca half of terminal segment), z1-z3 setae long; this segment medially with two subequally long dorsal setae, two ventral setae of unequal length (t1-t2). Terminal segment distally with two serrated claws (GM and $\mathrm{Gm}$ ), length of $\mathrm{Gm} \mathrm{ca} 2 / 3$ that of GM; medially with short g-seta and ventral aesthetasc $\mathrm{y} 3$, length of aesthetasc y3 and accompanying seta subequal.

Md PAlp (Fig. 3A). First segment with two large setae, one long and slender seta, and a short, smooth $\alpha$-seta. Second segment dorsally with three unequal long apical setae; ventrally with group of three long hirsute setae, one shorter hirsute seta and plumose, cone-shaped $\beta$-seta with pointed tip. Penultimate segment with three groups of setae: dorsally with group of four unequal, long, subapical setae; laterally with apical $\gamma$-seta and three further apical setae (two smooth, one hirsute), the former thin and long (length ca 2.2 times that of terminal segment); ventrally with two subapical setae, one very long (reaching beyond tip of terminal segment), one short (ca half length of terminal segment). Terminal segment elongated, bearing three claws and two shorter setae.

Mx1 (Fig. 3B). With two-segmented palp, basal segment of palp dorsally with group of five long, unequal apical setae; ventrally with one short subapical seta. Terminal segment very elongated (length ca 2.8 times width), apically with three claws and two setae. Third endite with two (one smooth, one serrated) large bristles. Sideways-directed bristles on first endite unequally long, length of short one ca half that of long one.

T1 (Fig. 3C-D). Protopodite with two unequally short a-setae, b- and d-setae absent, distally with ca 12 hirsute apical setae of unequal length. Endopodite with weakly built palp, with one very long, hirsute and two unequally short apical setae.

T2 (Fig. 4A). With d2 seta (d1 absent). Second segment with long e-seta (reaching tip of penultimate segment). Penultimate segment divided, proximal segment bearing long $\mathrm{f}$-seta (reaching beyond tip of terminal segment), distal segment with pair of apical setae (g-seta, one short), g-seta very long (with almost the same length as h1 seta). Terminal segment with two (one dorsal, one ventral) apical hl and $\mathrm{h} 3$ setae (length of former ca half that of claw, latter short) and serrated claw (h2), length of h2 longer than that of penultimate segment. 


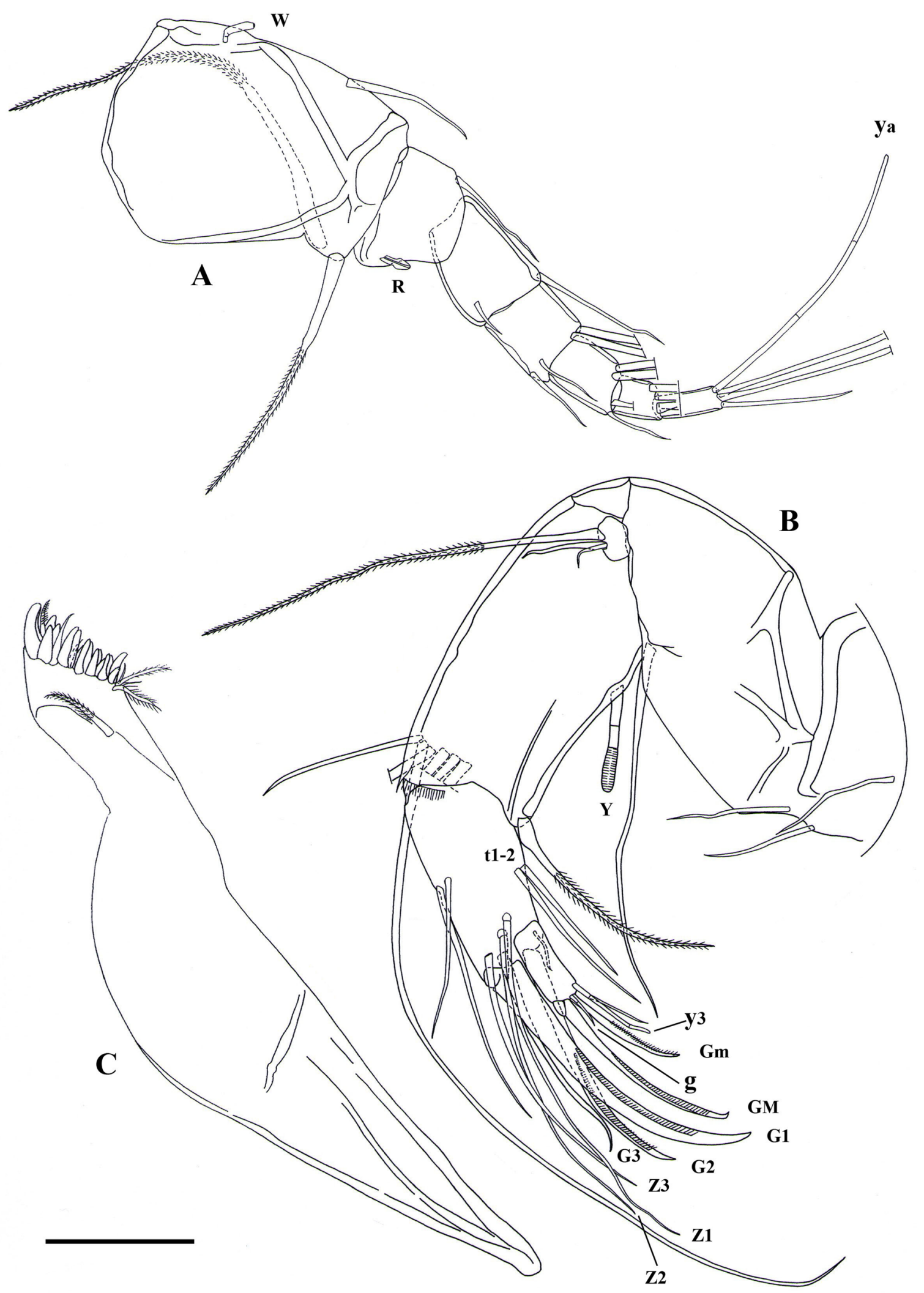

Fig. 2. Siamopsis renateae gen. et sp. nov., o (MSU-ZOC.190). A. A1. B. A2. C. Md coxa. Scale bar: $50 \mu \mathrm{m}$. 

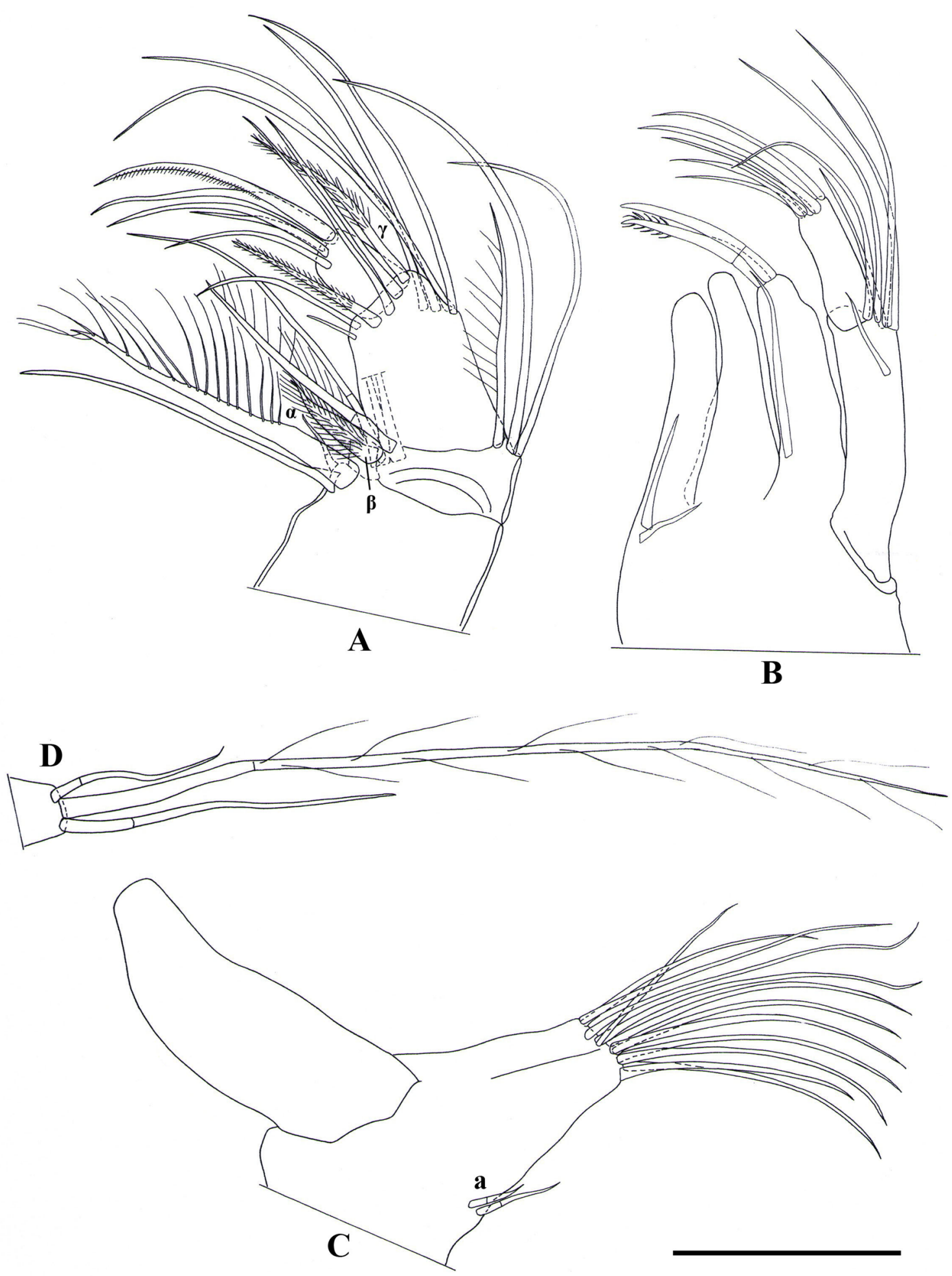

Fig. 3. Siamopsis renateae gen. et sp. nov., $q$ (MSU-ZOC.190). A. Md palp. B. Mx1. C. T1. D. T1, terminal part of endopodite. Scale bar: $50 \mu \mathrm{m}$. 


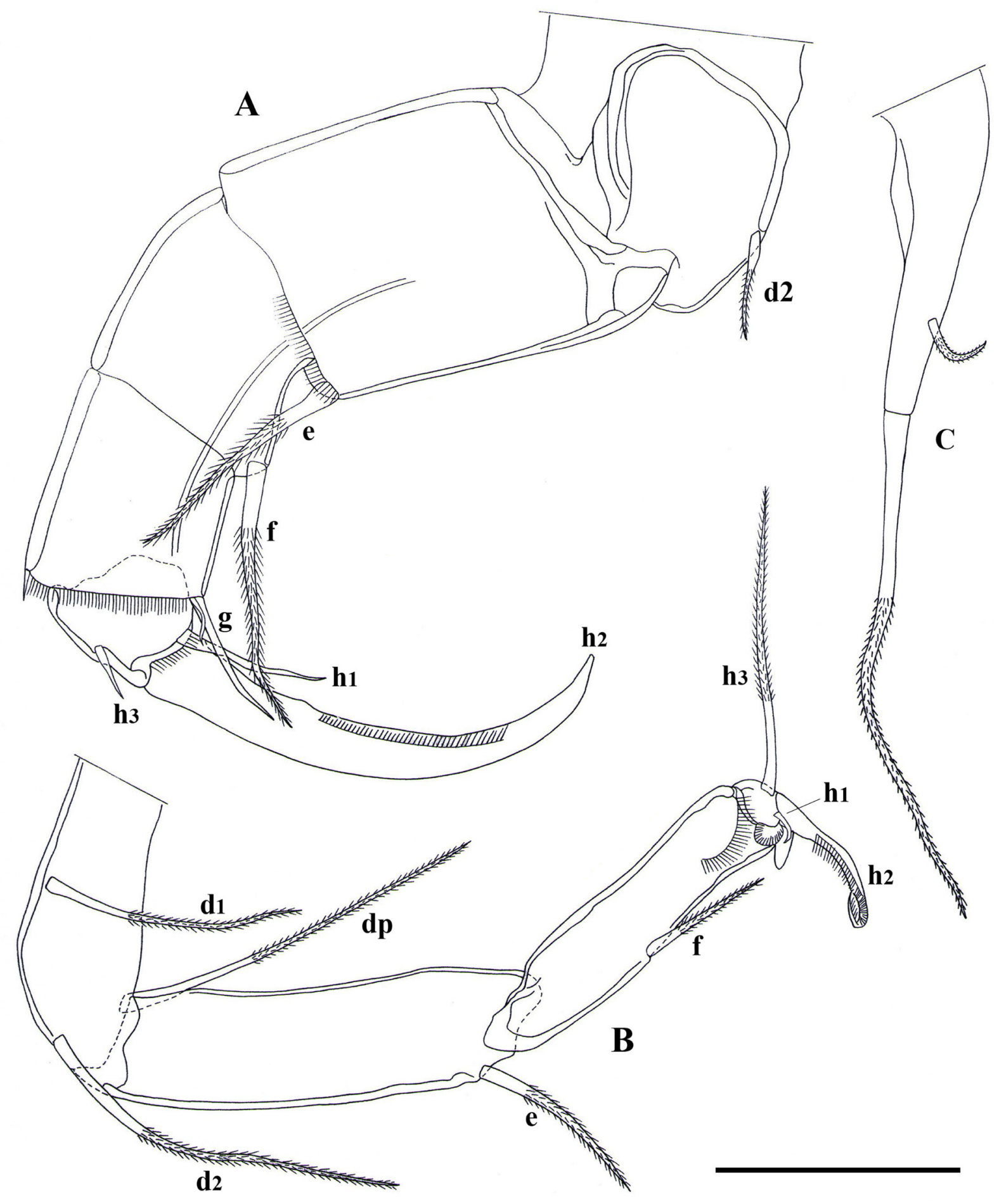

Fig. 4. Siamopsis renateae gen. et sp. nov., $q$ (MSU-ZOC.190). A. T2. B. T3. C. CR. Scale bar: $50 \mu \mathrm{m}$. 
T3 (Fig. 4B). A cleaning limb. First segment with long d1, d2 and dp setae, d1 and d2 setae subequal in length. Second segment with long apical e-seta (reaching half of next segment). Third segment with medially long f-seta (reaching tip of segment). Terminal segment with an apical pincer and one reflexed subapical seta, length of latter equal to that of third segment.

CR (Fig. 4C). Reduced, flagellum-like, of cylindrical shape, with a small lateral seta and long apical seta, length of latter ca 1.7 times that of ramus.

\section{Male \\ Unknown.}

\section{Ecology}

The new species has thus far been recorded from eight localities in the Northern and Northeastern provinces: Nakhon Ratchasima, Chaiyaphum, Phayao, Chiang Rai, Phitsanulok and Phetchabun. It occurs at a $\mathrm{pH}$ range of $6.5-7.2$, a temperature range of $26.1-29.5^{\circ} \mathrm{C}$ and a dissolved oxygen (DO) range of $3.20-7.80 \mathrm{mg} / \mathrm{l}$.

Siamopsis suttajiti gen. et sp. nov. urn:1sid:zoobank.org:act:9DFC2DC2-82F1-44A2-9762-F817055F8893

Figs $5-7,19 \mathrm{C}, 20$

\section{Diagnosis}

Carapace in lateral view elongated, dorsal margin arched, greatest height situated in front of mid-length. Carapace in dorsal view elliptical, with unevenly curved lateral margins (posterior half of carapace), anterior extremity pointed, RV overlapping LV anteriorly, ventrally and posteriorly. Valve surface set with long (rim-pore) setae and shallow pits dispersedly. LV in internal view with large selvage anteriorly, valve margins rounded, broader anteriorly, postero-dorsal plate of LV in internal view elongated, with posterior marginal tooth-like tubercle. RV in internal view with large selvage anteriorly, posterior margin slightly curved inwardly at postero-dorsal part, few small tubercle-like structures set beneath the posterior inner list along postero-ventral corner. Third endite of Mx1 with two large bristles, one distally serrated, the other one smooth. CR cylindrical in shape, with long flagellum-like seta (ca 2.4 times as long as ramus).

\section{Etymology}

This species is named after Prof. Dr. Maitree Suttajit (University of Phayao, Thailand) in appreciation of his encouragement and moral support over the years, especially during my research project on nonmarine ostracods in the southern part of Northeast Thailand.

\section{Material examined}

\section{Holotype}

THAILAND: + , with soft parts dissected in glycerine on a sealed glass slide and valves stored dry in a micropalaeontological slide (MSU-ZOC.195).

\section{Paratypes}

THAILAND: 2 우, stored as the holotype (MSU-ZOC.196-197); $3 q q$, carapaces stored dry in micropalaeontological slides (MSU-ZOC.198-200); 4 우 in 70\% EtOH. 


\section{Type locality}

THAILAND: Phayao Province, Muang District, Kwan Phayao (lake) (locality 9 in Fig. 20), 1909'28" N, 9054'39" E, 6 Oct. 2007. Accompanying ostracod fauna: Cypris subglobosa Sowerby, 1840, Stenocypris malayica Victor \& Fernando, 1981, Astenocypris papyracea (Sars, 1903), Bradleystrandesia weberi, Bradleytriebella lineata (Victor \& Fernando, 1981), Pseudostrandesia calapanensis (Tressler, 1937), P. mamarilorum, Strandesia kraepelini, Tanycypris siamensis Savatenalinton \& Martens, 2009, Cypretta sp. 3, Cypridopsis vidua (O.F. Müller, 1906), Siamopsis conspecta gen. et sp. nov. and Physocypria sp. 2.

\section{Differential diagnosis}

Siamopsis suttajiti gen. et sp. nov. can be distinguished by the morphology of the carapace in dorsal view and the postero-dorsal plate of the LV in internal view. The carapace in dorsal view is elongated, with unevenly curved lateral margins (the posterior half of carapace narrower) and the LV posterodorsal plate contains a tooth-like tubercle on the posterior marginal. Siamopsis suttajiti gen. et sp. nov. is similar to $S$. conspecta gen. et sp. nov. and $S$. khoratensis gen. et sp. nov. as they share a few small septa-like structures under the posterior inner list along the postero-ventral corner. The distinguishing features of S. suttajiti gen. et sp. nov. also appear in the soft parts morphology. For example, the length of the shortest seta on A1 terminal segment is markedly short, when compared to ya (ca $1 / 4$ length of ya). In other species of Siamopsis gen. nov., this seta is about half as long as ya. Additionally, the apical flagellum-like seta of CR is very long (more than two times that of the ramus) in S. suttajiti gen. et sp. nov. while it is less than two times that of the ramus in other species of Siamopsis gen. nov.

Measurements (mean, in $\mu \mathrm{m}$ )

$\mathrm{LV}(\mathrm{n}=2), \mathrm{L}=577, \mathrm{H}=335 ; \mathrm{RV}(\mathrm{n}=2), \mathrm{L}=584, \mathrm{H}=344$; carapace $(\mathrm{n}=2), \mathrm{L}=593, \mathrm{~W}=258$.

\section{Description}

\section{Female}

CARAPACE. In lateral view (Fig. 5A) elongated, dorsal margin arched, greatest height situated in front of mid-length, anterior margin rounded, posterior margin narrower rounded, ventral margin sinuous at ca mid-length, RV overlapping LV anteriorly, ventrally and posteriorly, valve surface set with long setae, long rim-pore setae and shallow pits dispersedly. Carapace in dorsal view (Fig. 5B, D) elliptical, with unevenly curved lateral margins (posterior half of carapace narrower), greatest width situated at midlength, anterior extremity pointed, posterior extremity rounded.

VALVES. LV in internal view (Fig. 5F, H) with large selvage anteriorly, valve margins rounded, broader anteriorly, ventral margin sinuous at mid-length, postero-dorsal plate elongated, with posterior marginal tooth-like tubercle, inner lamella anteriorly broader than posteriorly, without inner list. RV in internal view (Fig. 5G, I) with large selvage anteriorly, ventral margin sinuous at mid-length, posterior margin slightly curved inwardly at postero-dorsal part, inner lamella calcified with inner lists anteriorly and posteriorly, with few tiny tubercle-like structures under posterior inner list along postero-ventral corner.

A1 (Fig. 6A). Seven-segmented, first segment with large proximal Wouters organ, one long dorsosubapical seta (reaching mid-length of next segment) and two long ventro-apical setae. Second segment slightly wider than long, with one long dorso-apical seta (reaching tip of next segment) and Rome organ. Third segment bearing two setae: one long dorso-apical (reaching beyond tip of terminal segment) and one short ventro-apical. Fourth segment with two long dorsal setae and two short ventral setae (both reaching end of next segment). Fifth segment dorsally with two long setae, ventrally with two (one long, one short) setae, short one reaching mid-length of terminal segment. Penultimate segment with four long apical setae. Terminal segment with three (two long, one short) apical setae and very long aesthetasc ya, length of short seta ca $1 / 4$ that of aesthetasc ya. 


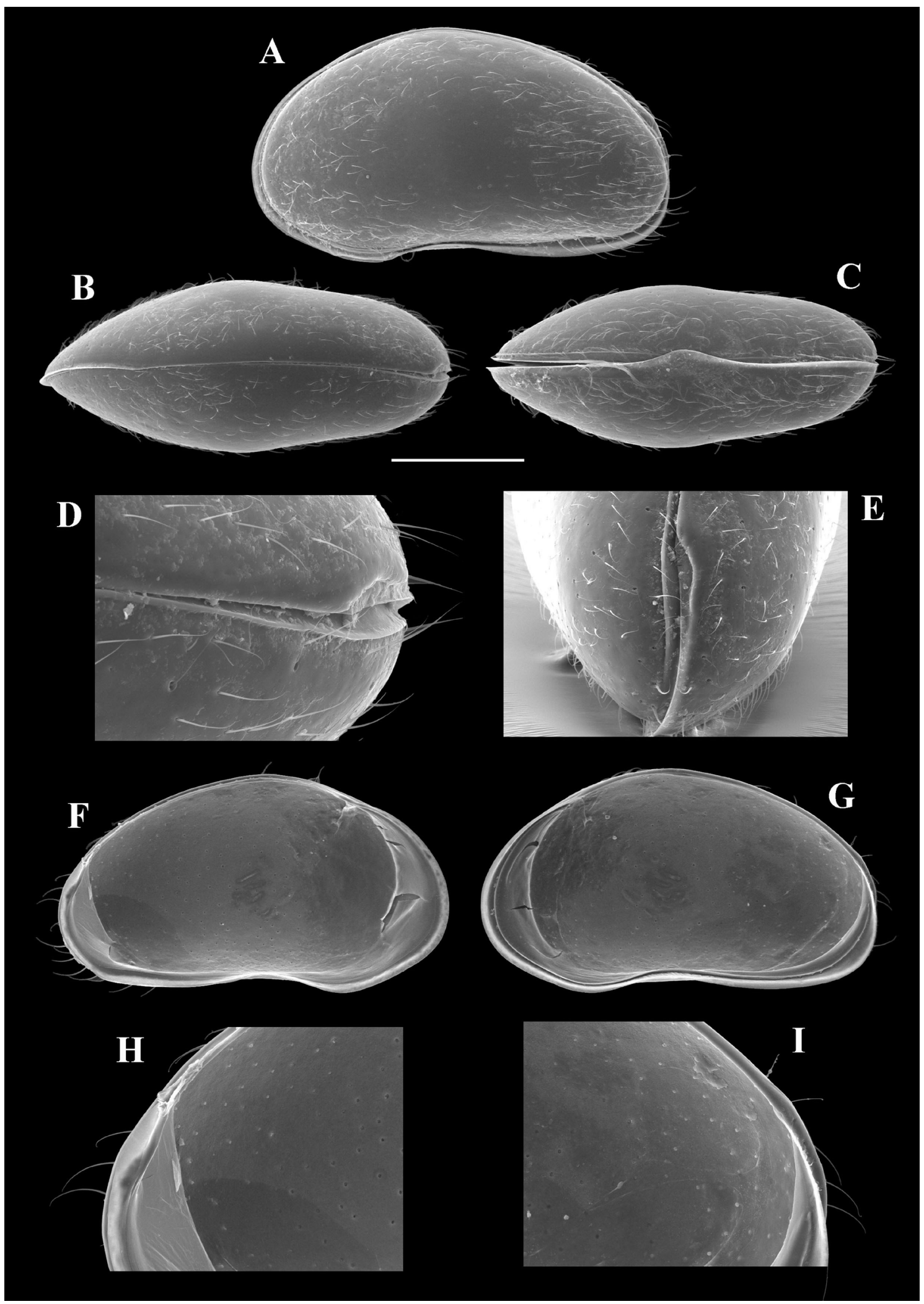

Fig. 5. Siamopsis suttajiti gen. et sp. nov., +. A. CpL (MSU-ZOC.198). B. CpD (MSU-ZOC.199). C. CpV (MSU-ZOC.200). D. Posterior end of CpD (MSU-ZOC.199). E. CpC (idem). F. LVi (MSUZOC.196). G. RVi (idem). H. Postero-dorsal part of LVi (idem). I. Postero-dorsal part of RVi (idem). Scale bar: A-C, $\mathrm{F}-\mathrm{G}=200 \mu \mathrm{m} ; \mathrm{D}=56 \mu \mathrm{m} ; \mathrm{E}=104 \mu \mathrm{m} ; \mathrm{H}-\mathrm{I}=87 \mu \mathrm{m}$. 

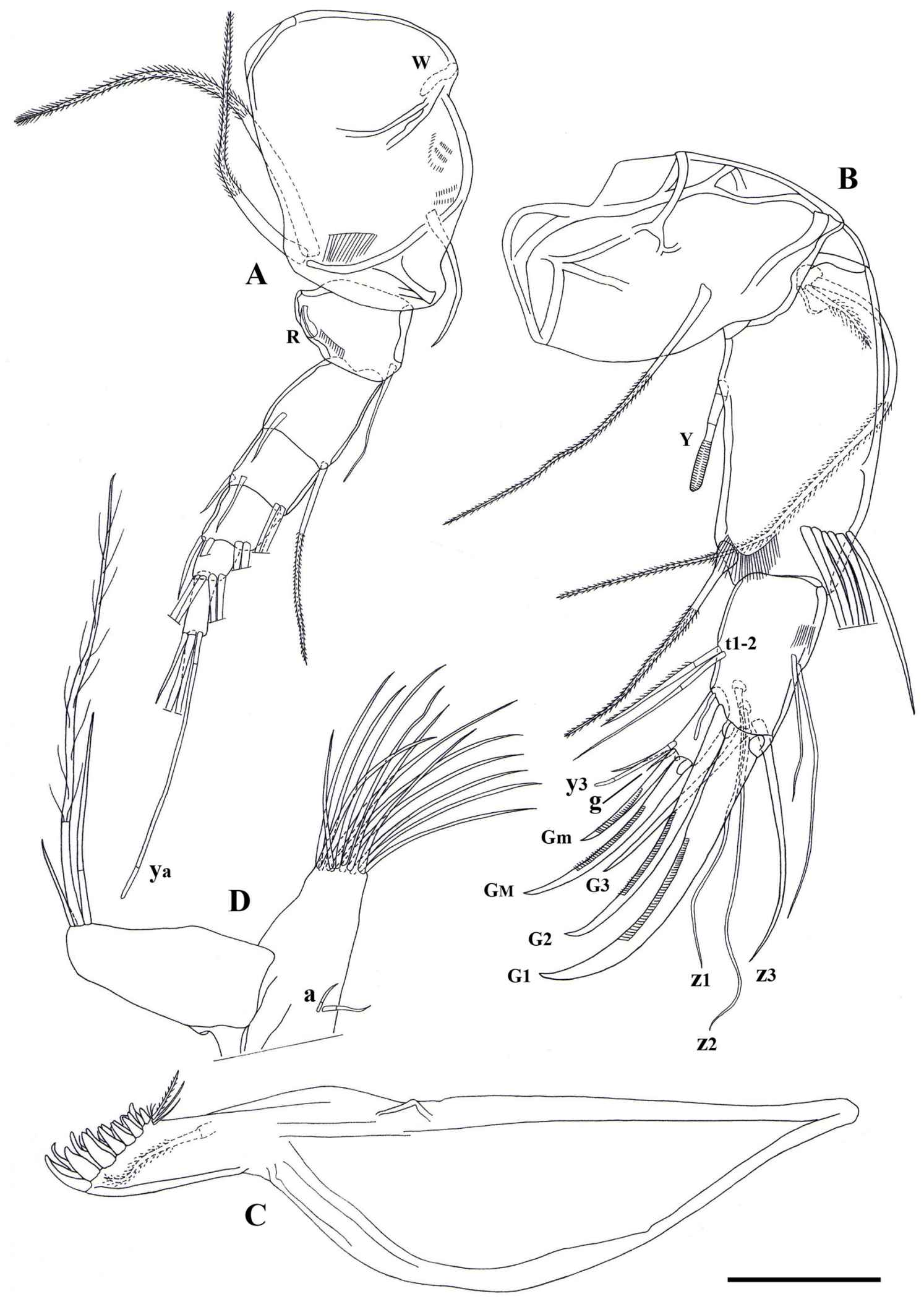

Fig. 6. Siamopsis suttajiti gen. et sp. nov., $q$ (MSU-ZOC.195). A. A1. B. A2. C. Md coxa. D. T1. Scale bar: $50 \mu \mathrm{m}$. 
A2 (Fig. 6B). Exopodite with three (one long, two short) setae, long one reaching beyond tip of first endopodal segment. First endopodal segment with five long (reaching far beyond tip of terminal claws) and one short natatory setae, shortest seta reaching end of penultimate segment, aesthetasc Y long, ventro-apical seta long, extending beyond tip of terminal segment. Penultimate segment undivided, distally with three serrated claws (G1, G2, G3), G2 shorter (length of G2 ca 6/t that of G1), aesthetasc y2 long (ca half length of terminal segment), z1-z3 setae long; this segment medially with two subequally long dorsal setae, two ventral setae of unequal length ( $\mathrm{t} 1-\mathrm{t} 2)$. Terminal segment distally with two serrated claws (GM and Gm), length of Gm ca $2 / 3$ that of GM; medially with short $g$-seta and ventral aesthetasc $\mathrm{y} 3$, length of accompanying seta ca $3 / 4$ that of aesthetasc $y 3$.

Md palp (Fig. 7A). First segment with two large setae, one long and slender seta, and a short, smooth $\alpha$-seta. Second segment dorsally with three unequally long apical setae; ventrally with group of three long hirsute setae, one shorter hirsute seta and plumose, cone-shaped $\beta$-seta with pointed tip. Penultimate segment with three groups of setae: dorsally with group of four unequal, long, subapical setae; laterally with apical $\gamma$-seta and three further apical setae (two smooth, one hirsute), the former thin and long (length ca 2.2 times that of terminal segment); ventrally with two subapical setae, one very long (reaching beyond tip of terminal segment), one short (ca half length of terminal segment). Terminal segment elongated, bearing three claws and two short setae.

Mx1 (Fig. 7B). With two-segmented palp, basal segment of palp dorsally with group of six long, unequal apical setae; ventrally with one short subapical seta. Terminal segment very elongated (length ca 2.7 times width), apically with three claws and two setae. Third endite with two (one smooth, one serrated) large bristles. Lateral bristles on first endite unequally long, length of long one ca 2.2 times that of short one.

T1 (Fig. 6D). Protopodite with two unequally short a-setae, b- and d-setae absent, distally with ca 14 hirsute apical setae of unequal length. Endopodite weakly built palp with one very long, hirsute and two unequally short apical setae.

T2 (Fig. 7C). With $\mathrm{d} 2$ seta (d1 absent). Second segment with short e-seta (reaching middle of penultimate segment). Penultimate segment divided, proximal segment bearing long f-seta (reaching tip of terminal segment), distal segment with pair of apical setae (very long g-seta, one short), the long one reaching beyond tip of terminal segment. Terminal segment with two (one dorsally, one ventrally) apical h1 and $\mathrm{h} 3$ setae (length of former ca $1 / 3$ that of claw, latter spine-like) and serrated claw (h2), length of $\mathrm{h} 2$ longer than that of penultimate segment.

T3 (Fig. 7D). A cleaning limb. First segment with long $\mathrm{d} 1$, $\mathrm{d} 2$ and $\mathrm{dp}$ setae, $\mathrm{d} 1$ and $\mathrm{d} 2$ setae subequal in length. Second segment with long apical e-seta (reaching half of next segment). Third segment with medially long f-seta (reaching tip of segment). Terminal segment with an apical pincer and one reflexed subapical seta, length of latter equal that of third segment.

CR (Fig. 7E). Reduced, flagellum-like, of cylindrical shape, with a small lateral seta and very long apical seta, length of latter ca 2.4 times that of ramus.

\section{Male \\ Unknown.}

\section{Ecology}

The new species has thus far been collected from only one locality in Phayao Province. It occurs at a $\mathrm{pH}$ of 7.1 , a temperature of $26.8^{\circ} \mathrm{C}$ and a DO of $7.16 \mathrm{mg} / 1$. 


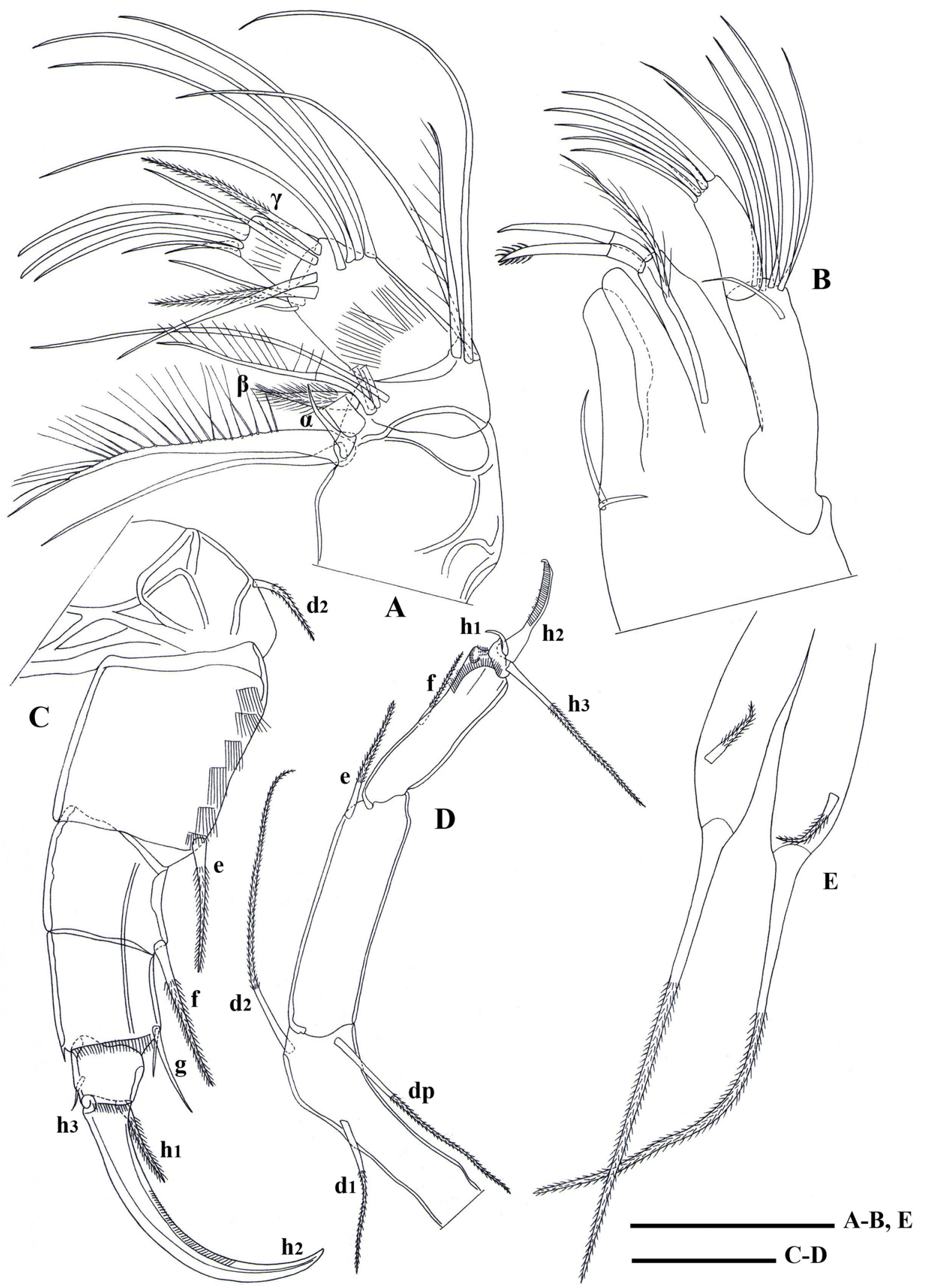

Fig. 7. Siamopsis suttajiti gen. et sp. nov., + (MSU-ZOC.195). A. Md palp. B. Mx1. C. T2. D. T3. E. CR. Scale bars: $50 \mu \mathrm{m}$. 


\section{Siamopsis conspecta gen. et sp. nov. urn:1sid:zoobank.org:act:AF502FC5-AE39-4017-8E88-7518CCCC8AC5}

Figs $8-10,19 \mathrm{~B}, 20$

\section{Diagnosis}

Carapace in lateral view elongated, dorsal margin arched, greatest height situated in front of mid-length, RV overlapping LV anteriorly, ventrally and posteriorly. Valve surface set with long (rim-pore) setae and shallow pits dispersedly. LV in internal view with large selvage anteriorly, valve margins rounded, broader anteriorly, postero-dorsal plate of LV in internal view broad, with large tooth-like tubercle at the centre. RV in internal view with large selvage anteriorly, posterior margin curved inwardly at posterodorsal part, outer margin of posterior inner list set with a series of small tubercle-like structures at postero-ventral corner. Third endite of Mx1 with two large bristles, one distally serrated, other one smooth. CR cylindrical in shape, with flagellum-like seta.

\section{Etymology}

The Latin word 'conspecta', meaning conspicuous, refers to the markedly well-developed tooth-like tubercle on the postero-dorsal plate of internal LV. This is the most prominent character of the new species.

\section{Material examined}

\section{Holotype}

THAILAND: 9 , with soft parts dissected in glycerine on a sealed glass slide and valves stored dry in a micropalaeontological slide (MSU-ZOC.201).

\section{Paratypes}

THAILAND: 1 , stored as the holotype (MSU-ZOC.202); 1 , carapace stored dry in a micropalaeontological slide (MSU-ZOC.203).

\section{Other material}

THAILAND: Phayao Province, Muang District, Kwan Phayao (lake) (locality 9 in Fig. 20), $19^{\circ} 09^{\prime} 28^{\prime \prime}$ N, 9054'39" E, 6 Oct. 2007. Accompanying ostracod fauna: Cypris subglobosa Sowerby, 1840, Stenocypris malayica, Astenocypris papyracea, Bradleystrandesia weberi, Bradleytriebella lineata, Pseudostrandesia calapanensis, P. mamarilorum, Strandesia kraepelini, Tanycypris siamensis, Cypretta sp. 3, Cypridopsis vidua, Siamopsis suttajiti gen. et sp. nov. and Physocypria sp. 2.

\section{Type locality}

THAILAND: Nakhon Ratchasima Province, Muang District, irrigation ditch (locality 1 in Fig. 20), $14^{\circ} 43^{\prime} 46^{\prime \prime}$ N, 104³3'56" E, 5 Oct. 2010. Accompanying ostracod fauna: Cypris subglobosa, Cyprinotus uenoi, Stenocypris cf. orientalis, Siamopsis khoratensis gen. et sp. nov., S. renateae gen. et sp. nov. and S. planitia gen. et sp. nov.

\section{Differential diagnosis}

Siamopsis conspecta gen. et sp. nov. is similar to S. suttajiti gen. et sp. nov. in terms of the carapace shape in lateral view and the presence of tiny tubercle-like structures along the posterior inner list at the postero-ventral corner of the RV. It can be distinguished by the morphology of the postero-dorsal plate of the LV. The plate is broad and contains a large tooth-like tubercle at the middle in Siamopsis conspecta gen. et sp. nov., whereas it is elongated and has a marginal tooth-like tubercle at the posterior part in S. suttajiti gen. et sp. nov. In addition, compared to the CR length, the apical flagellum-like seta is shorter in Siamopsis conspecta gen. et sp. nov. (very long in S. suttajiti gen. et sp. nov.). 
Measurements (mean, in $\mu \mathrm{m}$ )

$\mathrm{LV}(\mathrm{n}=2), \mathrm{L}=627, \mathrm{H}=352 ; \mathrm{RV}(\mathrm{n}=2), \mathrm{L}=631, \mathrm{H}=362$.

\section{Description}

\section{Female}

CARAPACE. In lateral view elongated, dorsal margin arched, greatest height situated in front of mid-length, anterior margin rounded, posterior margin narrower rounded, RV overlapping LV anteriorly, ventrally and posteriorly, valve surface set with long setae, long rim-pore setae and shallow pits dispersedly. Carapace in dorsal view elliptical, with greatest width situated at mid-length.

VALVES. LV in interior view (Fig. 8C) with large selvage anteriorly, valve margins rounded, broader anteriorly, ventral margin sinuous at ca mid-length, postero-dorsal plate of LV in internal view broad, with large tooth-like tubercle at centre, inner lamella calcified, anteriorly broader than posteriorly. RV in interior view (Fig. 8D) with large selvage anteriorly, ventral margin sinuous at mid-length, posterior margin curved inwardly at postero-dorsal part, inner lamella calcified with inner lists anteriorly and posteriorly, outer margin of lamella set with a series of small tubercles at postero-ventral corner.

A1 (Fig. 9A). Seven-segmented, first segment with large proximal Wouters organ, one long dorsosubapical seta (reaching mid-length of next segment) and two long ventro-apical setae. Second segment slightly wider than long, with one long dorso-apical seta (reaching tip of next segment) and Rome organ. Third segment bearing two setae: one long dorso-apical and one short ventro-apical. Fourth segment with two long dorsal setae and two short ventral setae (one reaching tip of fifth segment, another one spine-like). Fifth segment dorsally with two long setae, ventrally with two (one long, one short) setae, short one reaching beyond tip of next segment. Penultimate segment with four long apical setae. Terminal segment with three (two long, one short) apical setae and very long aesthetasc ya, length of short seta more than half that of aesthetasc ya.

A2 (Fig. 9B). Exopodite with three (one long, two short) setae, long one reaching beyond tip of first endopodal segment. First endopodal segment with five long (reaching far beyond tip of terminal claws) and one short natatory setae, shortest seta reaching tip of penultimate segment, aesthetasc Y long, ventroapical seta long, extending beyond tip of terminal segment. Penultimate segment undivided, distally with three serrated claws (G1, G2, G3), G2 shorter (length of G2 ca $6 / 7$ that of G1), aesthetasc y2 long (ca half that of terminal segment), z1-z3 setae long; this segment medially with two subequally long dorsal setae and two ventral setae of unequal length (t1-t2). Terminal segment distally with two serrated claws (GM and Gm), length of Gm ca $2 / 3$ that of GM; medially with short $g$-seta and ventral aesthetasc $\mathrm{y} 3$, length of accompanying seta $\mathrm{ca}^{2} / 3$ that of aesthetasc $\mathrm{y} 3$.

Md PALP (Fig. 10A). First segment with two large setae, one long and slender seta, and a short, smooth $\alpha$-seta. Second segment dorsally with three unequal long apical setae; ventrally with group of three long hirsute setae, one shorter hirsute seta and plumose, cone-shaped $\beta$-seta with pointed tip. Penultimate segment consisting of three groups of setae: dorsally with group of four unequal, long, subapical setae; laterally with apical $\gamma$-seta and three further apical setae (two smooth, one hirsute), the former thin and long (length ca 2.2 times of terminal segment); ventrally with two subapical setae, one very long (reaching beyond tip of terminal segment), one short (ca half of terminal segment). Terminal segment elongated bearing three claws and two shorter seta.

Mx1 (Fig. 10B). With two-segmented palp, basal segment of palp dorsally with group of five long, unequal apical setae; ventrally with one short subapical seta. Terminal segment very elongated (length ca 3 times of width), apically with three claws and two setae. Third endite with two (one smooth, one 
serrated) large bristles. Sideways-directed bristles on first endite unequally long, length of short one ca half that of long one.

T1 (Fig. 9D). Protopodite with two unequally short a-setae, b- and d-setae absent, distally with ca 12 hirsute apical setae of unequal length. Endopodite with weakly built palp, with one very long, hirsute and two unequally short apical setae.

T2 (Fig. 10C). With d2 seta (d1 absent). Second segment with short e-seta (reaching beyond mid-length of penultimate segment). Penultimate segment divided, proximal segment bearing long f-seta (reaching beyond tip of terminal segment), distal segment with pair of apical setae (long g-seta, one short), length of g-seta almost the same length as that of h1 seta. Terminal segment with two (one dorsally, one ventrally) apical h1 and h3 setae (length of former ca $1 / 3$ that of claw, latter spine-like) and serrated claw (h2), length of $h 2$ longer than that of penultimate segment.

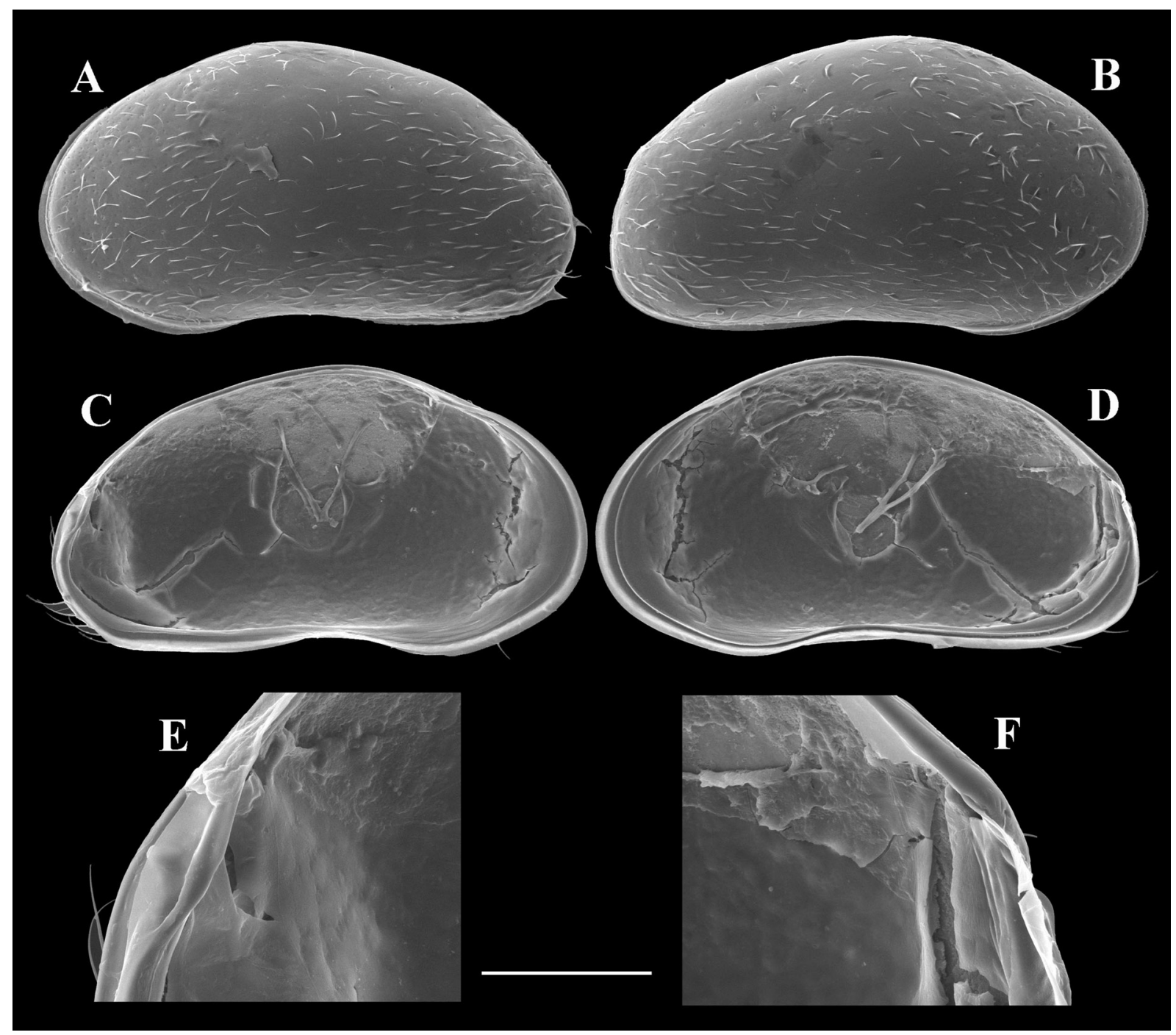

Fig. 8. Siamopsis conspecta gen. et sp. nov., q (MSU-ZOC.201). A. LVe. B. RVe (idem). C. LVi (idem). D. RVi (idem). E. Postero-dorsal part of LVi (idem). F. Postero-dorsal part of RVi (idem). Scale bar: $\mathrm{A}-\mathrm{D}=200 \mu \mathrm{m} ; \mathrm{E}-\mathrm{F}=56 \mu \mathrm{m}$. 


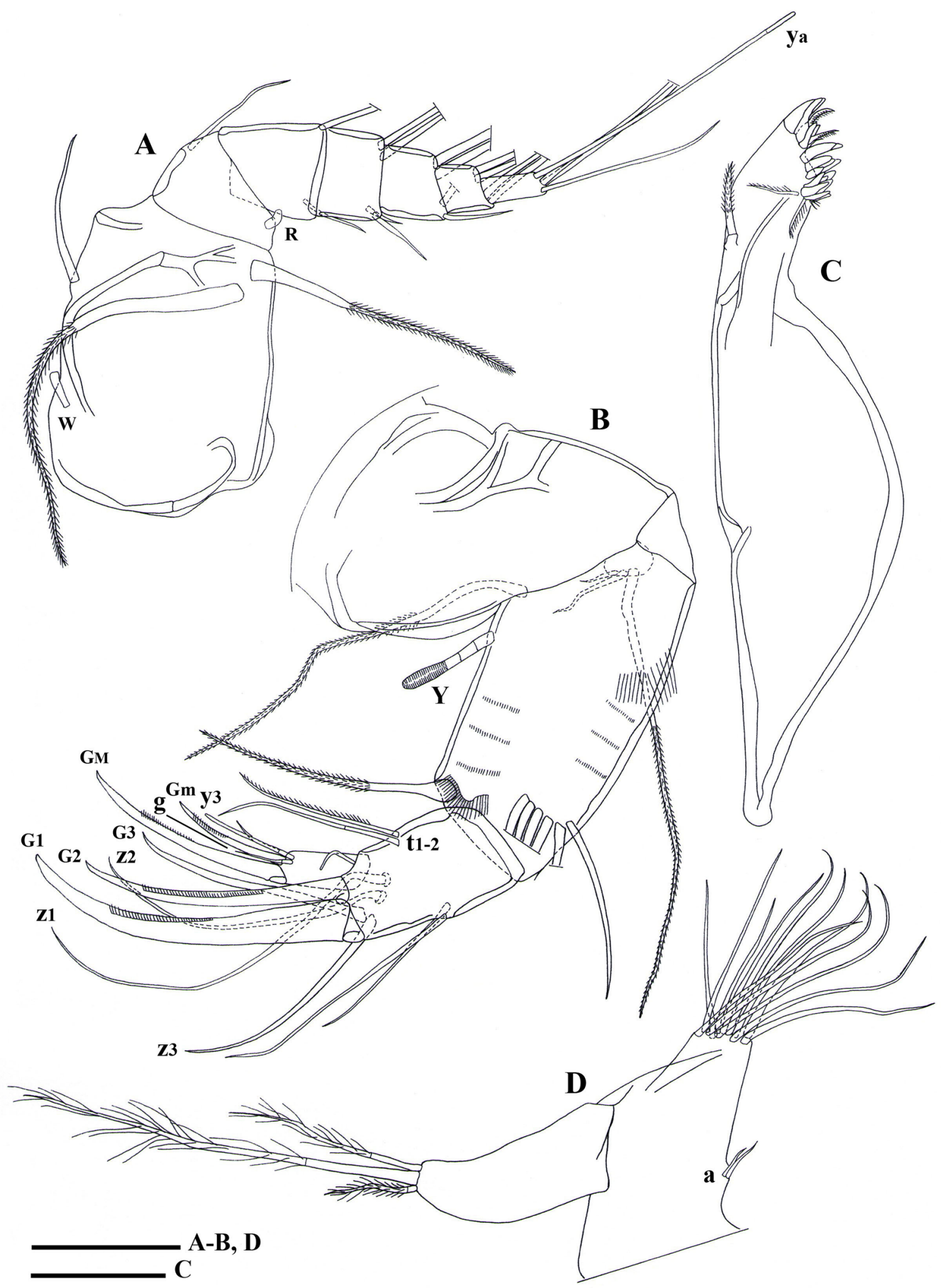

Fig. 9. Siamopsis conspecta gen. et sp. nov., $q^{(M S U-Z O C .201) . ~ A . ~ A 1 . ~ B . ~ A 2 . ~ C . ~ M d ~ c o x a . ~ D . T 1 . ~ S c a l e ~}$ bars: $50 \mu \mathrm{m}$. 


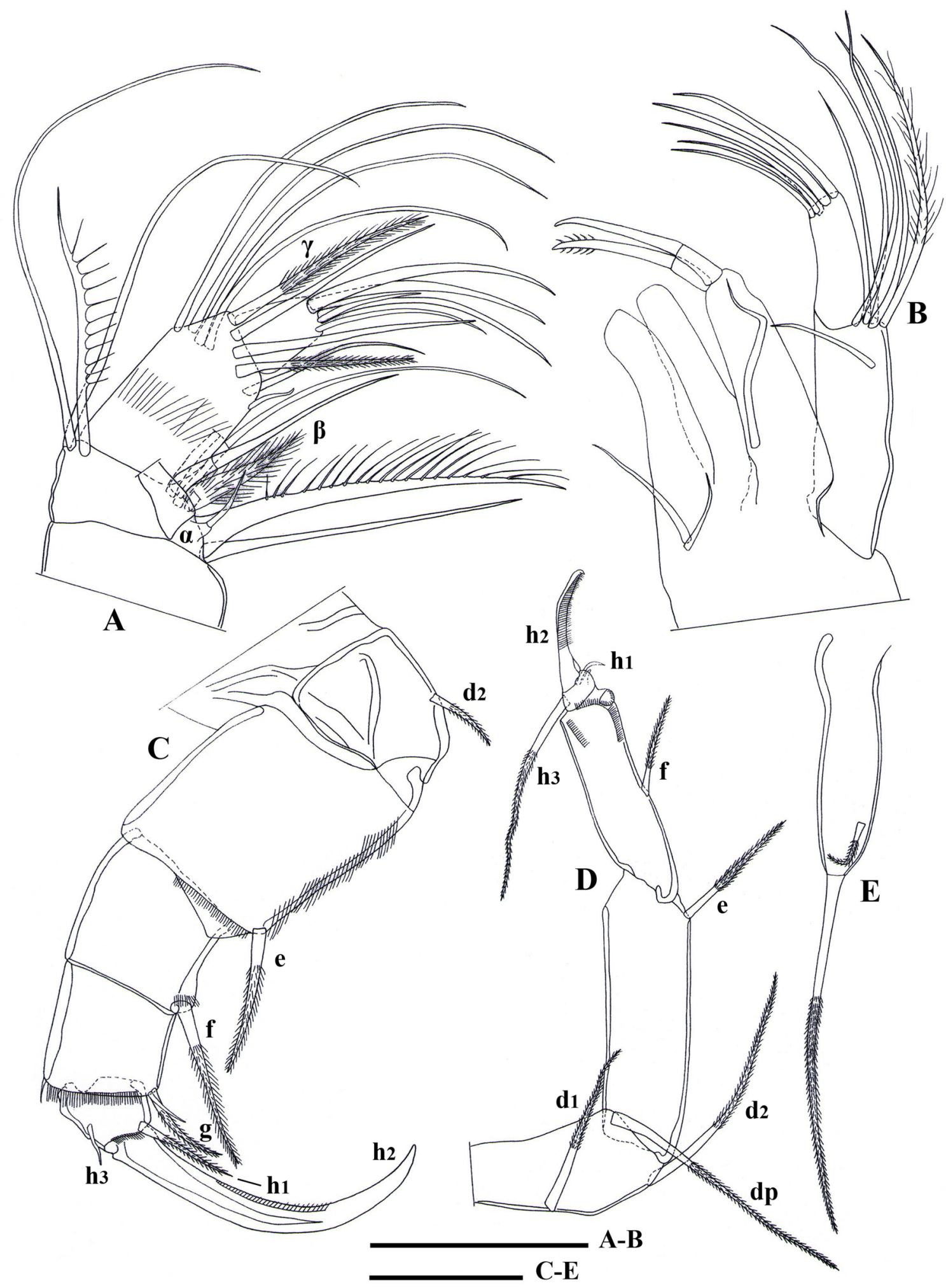

Fig. 10. Siamopsis conspecta gen. et sp. nov., o (MSU-ZOC.201). A. Md palp. B. Mx1. C. T2. D. T3. E. CR. Scale bars: $50 \mu \mathrm{m}$. 
T3 (Fig. 10D). A cleaning limb. First segment with long d1, d2 and dp setae, d1 and d2 setae subequal in length. Second segment with long apical e-seta (reaching half of next segment). Third segment with medially long f-seta (reaching tip of segment). Terminal segment with an apical pincer and one reflexed subapical seta, length of latter equal to that of third segment.

CR (Fig. 10E). Reduced, flagellum-like, cylindrical in shape, with a small lateral seta and long apical seta, length of latter ca 1.5 times that of ramus.

\section{Male}

Unknown.

\section{Ecology}

The new species has so far been collected from two bodies of water only in the Nakhon Ratchasima and Phayao Provinces. It occurs at a $\mathrm{pH}$ range of 7.0-7.1, a temperature range of $26.8-28.5^{\circ} \mathrm{C}$ and a $\mathrm{DO}$ of $7.16 \mathrm{mg} / \mathrm{l}$.

Siamopsis khoratensis gen. et sp. nov. urn:1sid:zoobank.org:act:3DCD40C9-3A9B-4E3A-AAAC-BDD6AEA1BD4C

Figs 11-14, 19D, 20

\section{Diagnosis}

Carapace in lateral view elongated, dorsal margin flat at middle part of carapace, RV overlapping LV anteriorly, ventrally and posteriorly. Valve surface set with long (rim-pore) setae and shallow pits dispersedly. LV in internal view with large selvage anteriorly, valve margins subequally rounded anteriorly and posteriorly, postero-dorsal plate broad, with a small anterior tooth-like tubercle. RV in internal view with large selvage anteriorly, posterior margin curved inwardly at slightly above mid height, posterior inner list internally set with small tubercle-like structures at postero-ventral part. Third endite of Mx1 with two large bristles, one distally serrated, one smooth. CR cylindrical in shape, with flagellum-like seta.

\section{Etymology}

The species is named after Nakhon Ratchasima Province, also called "Khorat", where the new species was discovered.

\section{Material examined}

\section{Holotype}

THAILAND: + , with soft parts dissected in glycerine on a sealed glass slide and valves stored dry in a micropalaeontological slide (MSU-ZOC.204).

\section{Paratypes}

THAILAND: 1 , stored as the holotype (MSU-ZOC.205); 1 , carapace stored dry in a micropalaeontological slide (MSU-ZOC.206).

\section{Type locality}

THAILAND: Nakhon Ratchasima Province, Muang District, irrigation ditch (locality 1 in Fig. 20), $14^{\circ} 43^{\prime} 46^{\prime \prime} \mathrm{N}, 104^{\circ} 33^{\prime} 56^{\prime \prime}$ E, 5 Oct. 2010. Accompanying ostracod fauna: Cypris subglobosa, Cyprinotus uenoi, Stenocypris cf. orientalis, Siamopsis suttajiti gen. et sp. nov., S. renateae gen. et sp. nov. and S. planitia gen. et sp. nov. 


\section{Differential diagnosis}

Siamopsis khoratensis gen. et sp. nov. has S. planitia gen. et sp. nov. as its closest congener. The obvious diagnostic characters are the morphology of the postero-dorsal plate of the LV in internal view and of the RV posterior inner list. The plate is broad and has a small tooth-like tubercle at the anterior part in S. khoratensis gen. et sp. nov., while it is elongated and has no tooth-like tubercle in S. planitia gen. et sp. nov. The RV posterior inner list is set with small tubercle-like structures at the postero-ventral part in $S$. khoratensis gen. et sp. nov., whereas it is smooth in S. planitia gen. et sp. nov.

Measurements (mean, in $\mu \mathrm{m})$

$\mathrm{LV}(\mathrm{n}=2), \mathrm{L}=616, \mathrm{H}=371 ; \mathrm{RV}(\mathrm{n}=2), \mathrm{L}=626, \mathrm{H}=373$.

\section{Description}

\section{Female}

CARAPACE. In lateral view elongated, dorsal margin flat at middle part of carapace, both margins subequally rounded anteriorly and posteriorly, RV overlapping LV anteriorly, ventrally and posteriorly, valve surface set with long setae, long rim-pore setae and shallow pits dispersedly (Fig. 11A-B). Carapace in dorsal view elliptical, with greatest width situated at mid-length.

VALVES. LV in interior view (Fig. 11C) with large selvage anteriorly, valve margins subequally rounded anteriorly and posteriorly, ventral margin sinuous at ca mid-length, postero-dorsal plate broad, set with a small anterior tooth-like tubercle, inner lamella anteriorly broader than posteriorly. RV in interior view (Fig. 11D) with large selvage anteriorly, valve margins subequally rounded anteriorly and posteriorly, ventral margin sinuous at ca mid-length, posterior margin recurved inwardly slightly above mid height, calcified inner lamella with inner lists anteriorly and posteriorly, postero-ventral inner-list internally set with small tubercle-like structures.

A1 (Fig. 12A). Seven-segmented, first segment with large proximal Wouters organ, one long dorsosubapical seta (reaching beyond tip of next segment) and two long ventro-apical setae. Second segment slightly wider than long, with one long dorso-apical seta (reaching tip of next segment) and Rome organ. Third segment bearing two setae: one long dorso-apical (reaching tip of penultimate segment) and one short ventro-apical setae. Fourth segment with two long dorsal setae and two short ventral setae (both reaching beyond half of fifth segment). Fifth segment dorsally with two long setae, ventrally with two (one long, one short) setae, short one reaching mid-length of terminal segment. Penultimate segment with four long apical setae. Terminal segment with three (two long, one short) apical setae and very long aesthetasc ya, length of short seta ca half that of aesthetasc ya.

A2 (Fig. 12B). Exopodite with three (one long, two short) setae, long one reaching beyond tip of first endopodal segment. First endopodal segment with five long (reaching far beyond tip of terminal claws) and one short natatory setae, length of shortest seta ca half that of penultimate segment, aesthetasc $Y$ long, ventro-apical seta long, extending beyond tip of terminal segment. Penultimate segment undivided, distally with three serrated claws (G1, G2, G3), G2 shorter (length of G2 ca 6/7 that of G1), aesthetasc y2 long (ca half that of terminal segment), z1-z3 setae long; this segment medially with two subequally long dorsal setae and two ventral setae of unequal length (t1-t2). Terminal segment distally with two serrated claws (GM and Gm), length of Gm slightly more than half that of GM; medially with short g-seta and ventral aesthetasc $y 3$, length of accompanying seta ca $2 / 3$ that of aesthetasc $y 3$.

MD PALP (Fig. 13A). First segment with two large setae, one long and slender seta, and a short, smooth $\alpha$-seta. Second segment dorsally with three unequally long apical setae; ventrally with group of three long hirsute setae, one shorter hirsute seta and plumose, cone-shaped $\beta$-seta with pointed tip. Penultimate segment consisting of three groups of setae: dorsally with group of four unequal, long, subapical setae; 

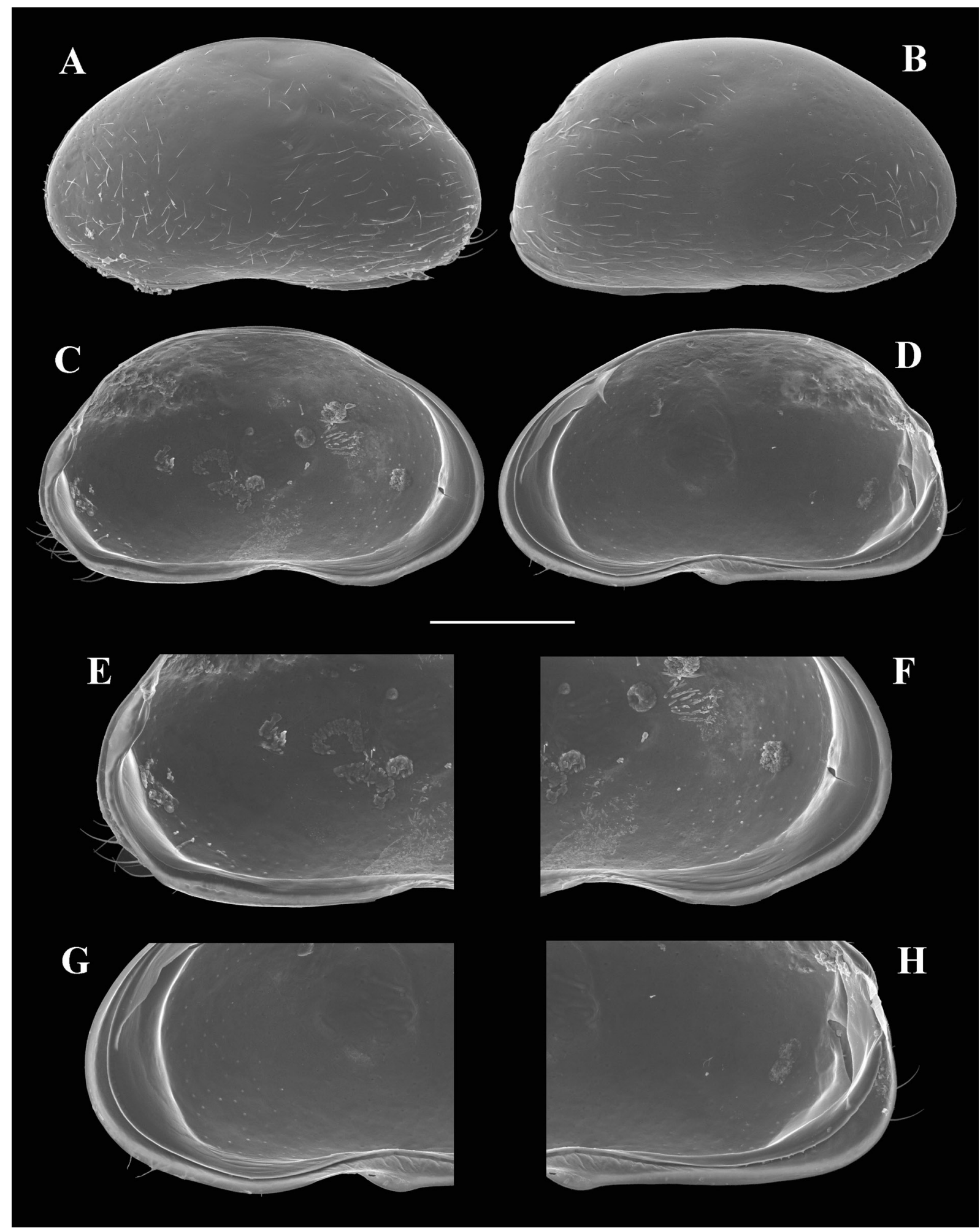

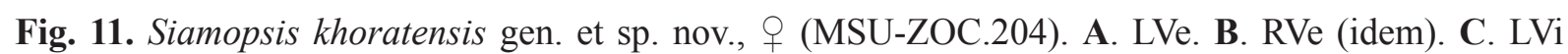
(idem). D. RVi (idem). E. Posterior part of LVi (idem). F. Anterior part of LVi (idem). G. Anterior part of RVi (idem). H. Posterior part of RVi (idem). Scale bar: A-D = $200 \mu \mathrm{m}$; E-H $=140 \mu \mathrm{m}$. 
laterally with apical $\gamma$-seta and three further apical setae (two smooth, one hirsute), the former thin and long (length ca 2.2 times that of terminal segment); ventrally with two subapical setae, one very long (reaching beyond tip of terminal segment), one short (ca half that of terminal segment). Terminal segment elongated, bearing three claws and two shorter setae.

Mx1 (Fig. 13B). With two-segmented palp, basal segment of palp dorsally with group of five long, unequal apical setae; ventrally with one short subapical seta. Terminal segment very elongated (length ca 3.3 times width), apically with three claws and two setae. Third endite with two (one smooth, one

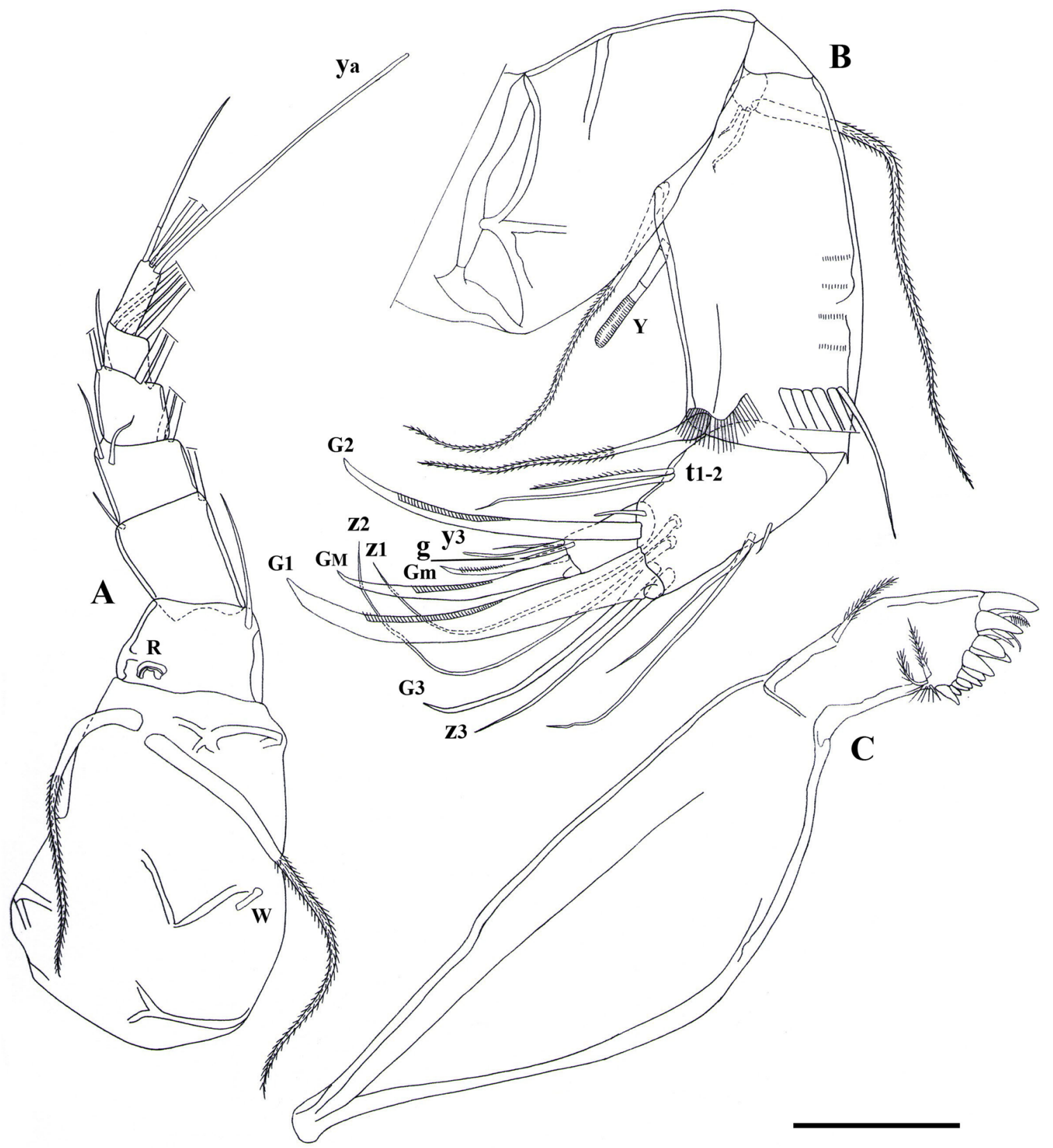

Fig. 12. Siamopsis khoratensis gen. et sp. nov., + (MSU-ZOC.204). A. A1. B. A2. C. Md coxa. Scale bar: $50 \mu \mathrm{m}$. 
serrated) large bristles. Sideways-directed bristles on first endite unequally long, length of short one ca half that of long one.

T1 (Fig. 13C-D). Protopodite with two unequally short a-setae, b- and d-setae absent, distally with ca 11 hirsute apical setae of unequal length. Endopodite a weakly built palp, with one very long, hirsute and two unequally short apical setae.

T2 (Fig. 14A). With d2 seta (d1 absent). Second segment with short e-seta (reaching mid-length of penultimate segment). Penultimate segment divided, proximal segment bearing long f-seta (reaching beyond tip of terminal segment), distal segment with pair of apical setae (long g-seta, one short), length of g-seta almost the same as that of h1 seta. Terminal segment with two (one dorsally, one ventrally) apical h1 and h3 setae (length of former ca $1 / 3$ that of claw, latter short) and serrated claw (h2), length of $\mathrm{h} 2$ longer than that of penultimate segment.

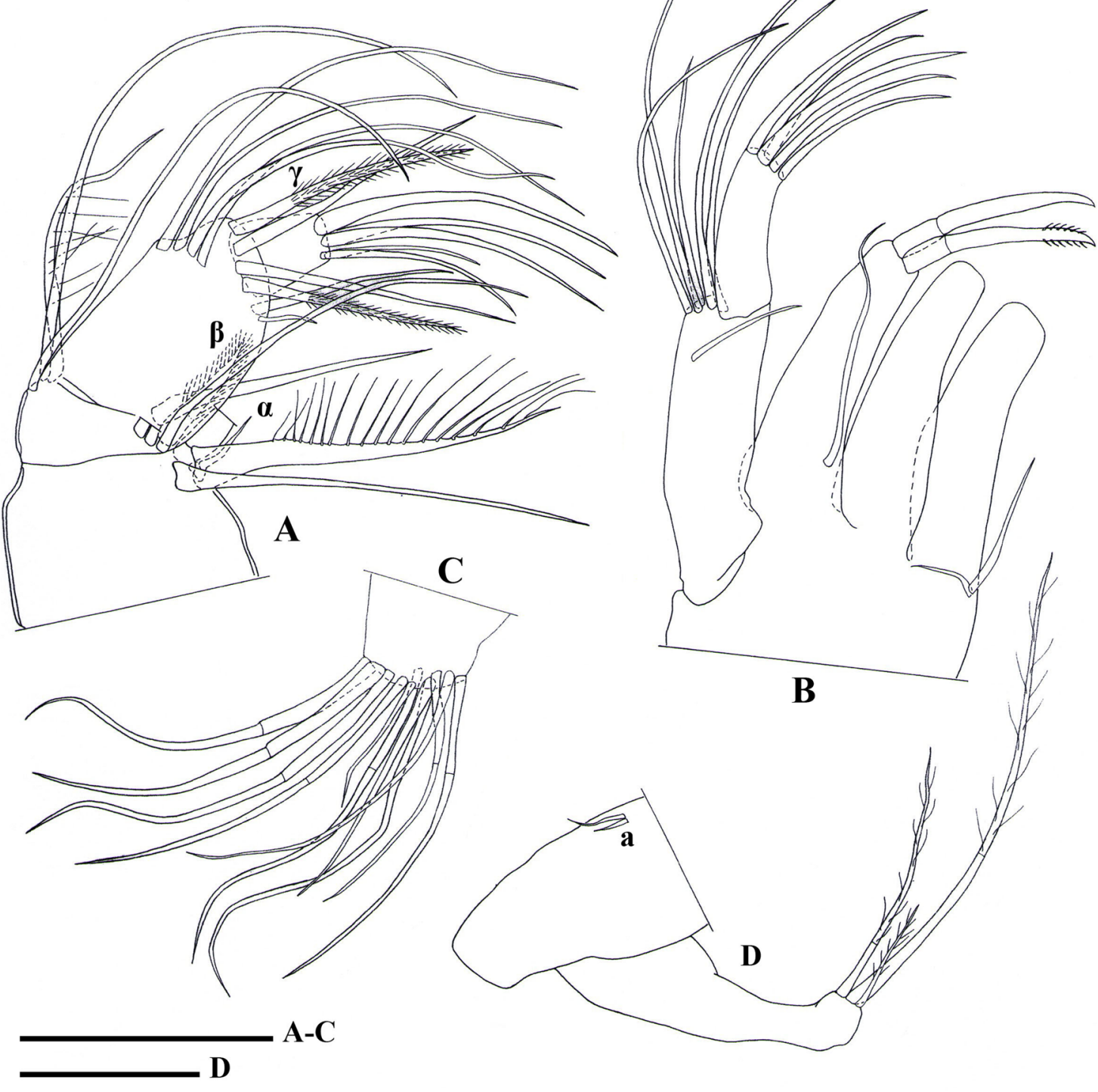

Fig. 13. Siamopsis khoratensis gen. et sp. nov.,, (MSU-ZOC.204). A. Md palp. B. Mx1. C. T1, apical setae on protopodite. D. T1. Scale bars: $50 \mu \mathrm{m}$. 
T3 (Fig. 14B). A cleaning limb. First segment with long d1, d2 and dp setae, d1 and d2 setae subequal in length. Second segment with long apical e-seta (reaching half of next segment). Third segment with medially long f-seta (reaching tip of segment). Terminal segment with an apical pincer and one reflexed subapical seta, length of latter equal to that of third segment.

CR (Fig. 14C). Reduced, flagellum-like, cylindrical in shape, with a small lateral seta and long apical seta, length of latter ca 1.8 times that of ramus.

\section{Male}

Unknown.

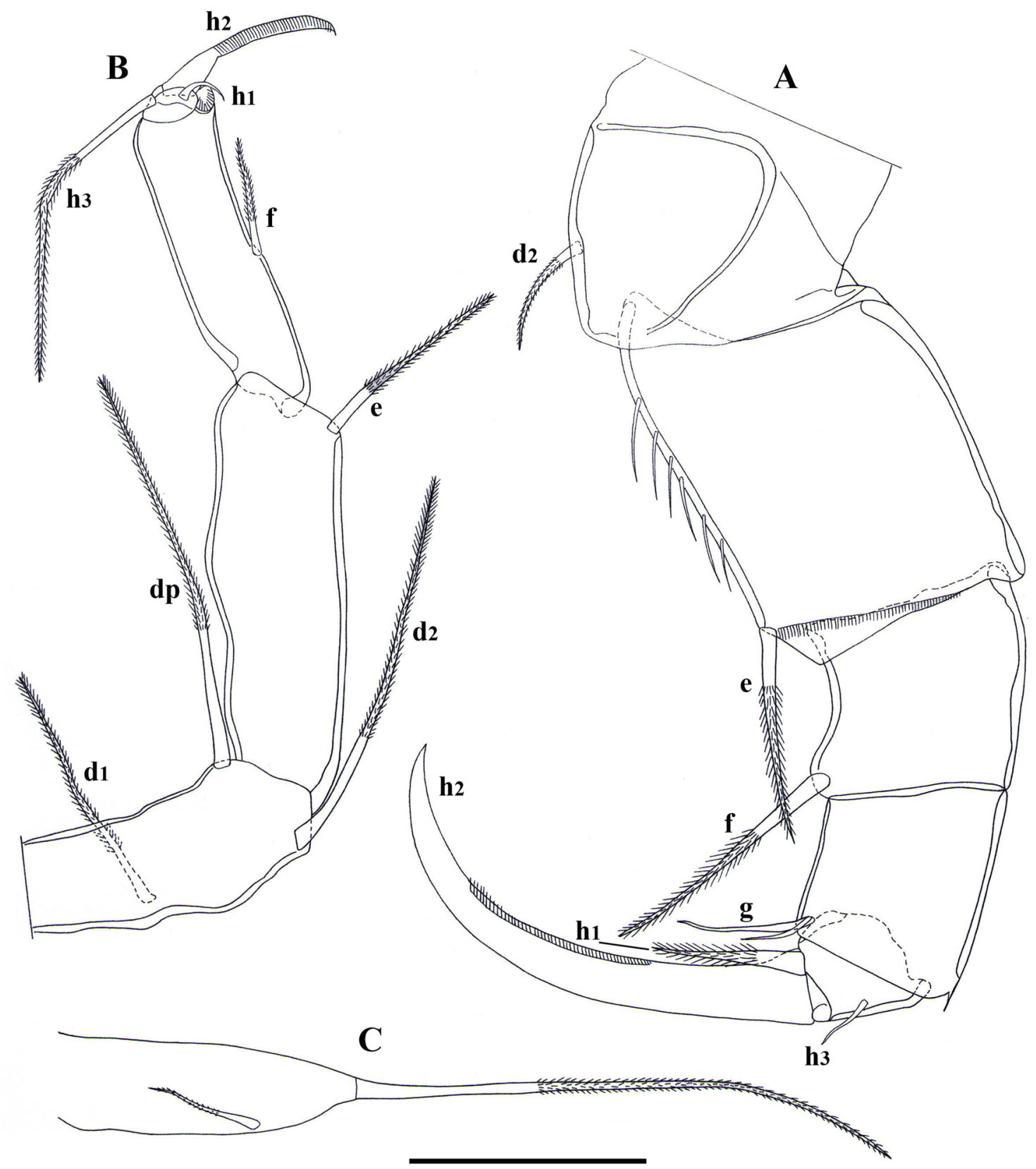

Fig. 14. Siamopsis khoratensis gen. et sp. nov., + (MSU-ZOC.204). A. T2. B. T3. C. CR. Scale bar: $50 \mu \mathrm{m}$. 


\section{Ecology}

The new species has been encountered at only one locality, in Nakhon Ratchasima Province. It occurs at a pH of 7.0 and a temperature of $28.5^{\circ} \mathrm{C}$.

Siamopsis planitia gen. et sp. nov.

urn:lsid:zoobank.org:act:BFF56BA9-BBB4-4B5D-8B3F-221F29768F07

Figs 15-18, 19E, 20

\section{Diagnosis}

Carapace in lateral view elongated, dorsal margin flat at middle part of carapace, RV overlapping LV anteriorly, ventrally and posteriorly, valve surface set with long (rim-pore) setae and shallow pits dispersedly. LV in internal view with large selvage anteriorly, valve margins subequally rounded anteriorly and posteriorly, postero-dorsal plate elongated, without tooth-like tubercle. RV in internal view with large selvage anteriorly, posterior margin curved inwardly at postero-dorsal part, posteroventral part slightly angulate, without small tubercle-like structures under inner list. Mx1 third endite with two (one smooth, one serrated) large bristles. CR cylindrical shape, with flagellum-like seta.

\section{Etymology}

The specific epithet "planitia" refers to the appearance of a dorsal margin at the middle part of the carapace in lateral view, which is similar to the summit of a plateau. This is the most prominent character of the new species.

\section{Material examined}

Holotype

THAILAND: + , with soft parts dissected in glycerine on a sealed glass slide and valves stored dry in a micropalaeontological slide (MSU-ZOC.208).

\section{Paratypes}

THAILAND: 1 , stored as the holotype (MSU-ZOC.208); 1 , carapace stored dry in a micropalaeontological slide (MSU-ZOC.209); 2 우 in 70\% EtOH.

\section{Other material}

THAILAND: Nakhon Ratchasima Province: Sikhiu District, Sub Pradu Reservoir (locality 2 in Fig. 20), $14^{\circ} 57^{\prime} 57^{\prime \prime} \mathrm{N}, 102^{\circ} 05^{\prime} 03^{\prime \prime} \mathrm{E}, 5$ Oct. 2007. Accompanying ostracod fauna: Hemicypris ovata (Sars, 1903), Chrissia humilis, Potamocypris sp. and Physocypria sp. 3. - Nakhon Ratchasima Province: Sikhiu District, Lam Taklong Dam (locality 10 in Fig. 20), 1451'49" N, 101³3'43" E, 20 Sep. 2005. Accompanying ostracod fauna: Hemicypris exiqua, Physocypria sp. 3 and Strandesia (juveniles); collected on 6 February 2006, accompanying ostracod fauna: Cypridopsis vidua, Cypridopsine sp. and Physocypria sp. 3. - Chiang Mai Province: Mae Kuang Dam (locality 11 in Fig. 20), 18 55'17" N, 99 07'26" E, 10 Feb. 2006. Accompanying ostracod fauna: Alicenula serricaudata (Klie, 1935), Cypridopsine sp. and Chrissia (juveniles). - Phetchabun Province: Muang District, Nong Naree (swamp) (locality 6 in Fig. 20), 16 26'24" N, 101 08'29" E, 9 Oct. 2007. Accompanying ostracod fauna: Bradleycypris vittata, Bradleystrandesia weberi, Strandesia kraepelini, Cypretta sp. 3, Potamocypris sp., Siamopsis renateae gen. et sp. nov., Physocypria sp. 2 and Physocypria sp. 3.

\section{Type locality}

THAILAND: Nakhon Ratchasima Province, Muang District, irrigation ditch (locality 1 in Fig. 20), $14^{\circ} 43^{\prime} 46^{\prime \prime} \mathrm{N}, 104^{\circ} 33^{\prime} 56^{\prime \prime}$ E, 5 Oct. 2010. Accompanying ostracod fauna: Cypris subglobosa, Cyprinotus 
uenoi, Stenocypris cf. orientalis, Siamopsis conspecta gen. et sp. nov., S. khoratensis gen. et sp. nov. and S. renateae gen. et sp. nov.

\section{Differential diagnosis}

Siamopsis planitia gen. et sp. nov. is closely related to $S$. khoratensis gen. et sp. nov. The species is characterized by the presence of a flat, slightly concave dorsal margin at the middle part of the carapace in lateral view, the naked (without tooth-like tubercle) elongated postero-dorsal plate of the LV and the absence of small tubercle-like structures under the inner list at the postero-ventral part of the RV.

Measurements (mean, in $\mu \mathrm{m}$ )

LV ( $n=2), L=667, H=373 ; R V(n=2), L=599, H=378$.

\section{Description}

\section{Female}

CARAPACE. In lateral view (Fig. 15A) elongated, dorsal margin flat at the middle part of carapace, both margins subequally rounded anteriorly and posteriorly, RV overlapping LV anteriorly, ventrally and posteriorly, valve surface set with long (rim-pore) setae and shallow pits dispersedly (Fig. 15D). Carapace in dorsal view elliptical, with greatest width situated at mid-length.

VALVES. LV in internal view (Fig. 15B) with large selvage anteriorly, valve margins subequally rounded anteriorly and posteriorly, postero-dorsal plate elongated, without tooth-like tubercle, calcified inner lamella anteriorly broader than posteriorly, with inner lists. RV in internal view (Fig. 15C) with large selvage anteriorly, posterior margin curved inwardly situated at postero-dorsal part, postero-ventral part slightly angulate, without small tubercle-like structures under inner list.

A1 (Fig. 16A). Seven-segmented, first segment with large proximal Wouters organ, one long dorsosubapical seta (reaching mid-length of next segment) and two long ventro-apical setae. Second segment slightly wider than long, with one long dorso-apical seta (reaching mid-length of next segment) and Rome organ. Third segment bearing two setae: one long dorso-apical (reaching tip of penultimate segment) and one ventro-apical spine-like setae. Fourth segment with two long dorsal setae and two short ventral setae (both reaching beyond half of fifth segment). Fifth segment dorsally with two long setae, ventrally with two (one long, one short) setae, short one reaching beyond tip of next segment. Penultimate segment with four long apical setae. Terminal segment with three (two long, one short) apical setae and very long aesthetasc ya, length of short seta more than half that of aesthetasc ya.

A2 (Fig. 16B). Exopodite with three (one long, two short) setae, long one reaching beyond tip of first endopodal segment. First endopodal segment with five long (reaching far beyond tip of terminal claws) and one short natatory setae, length of the shortest seta ca half that of penultimate segment, aesthetasc $\mathrm{Y}$ long, ventro-apical seta long, extending beyond tip of terminal segment. Penultimate segment undivided, distally with three serrated claws (G1, G2, G3), G2 shorter (length of G2 ca $6 / 7$ that of G1), aesthetasc y2 long (ca half of terminal segment), $\mathrm{z} 1-\mathrm{z} 3$ setae long; this segment medially with two subequally long dorsal setae, two ventral setae of unequal length (t1-t2). Terminal segment distally with two serrated claws (GM and $\mathrm{Gm}$ ), length of $\mathrm{Gm} \mathrm{ca} 2 / 3$ that of GM; medially with short $g$-seta and ventral aesthetasc $\mathrm{y} 3$, length of accompanying seta ca $3 / 4$ that of aesthetasc $y 3$.

MD PALP (Fig. 17A). First segment with two large setae, one long and slender seta, and a short, smooth $\alpha$-seta. Second segment dorsally with three unequally long apical setae; ventrally with group of three long hirsute setae, one shorter hirsute seta and plumose, cone-shaped $\beta$-seta with pointed tip. Penultimate segment consisting of three groups of setae: dorsally with group of four unequal, long, subapical setae; laterally with apical $\gamma$-seta and three further apical setae (two smooth, one hirsute), the former thin and 
long (length ca 2 times that of terminal segment); ventrally with two subapical setae, one very long (reaching beyond tip of terminal segment), one short (ca half length of terminal segment). Terminal segment elongated, bearing three claws and two shorter setae.

Mx1 (Fig. 17B). With two-segmented palp, basal segment of palp dorsally with group of five long, unequal apical setae; ventrally with one short subapical seta. Terminal segment very elongated (length ca 3 times that of width), apically with three claws and two setae. Third endite with two (one smooth, one serrated) large bristles. Sideways-directed bristles on first endite unequally long, length of short one ca half that of long one.

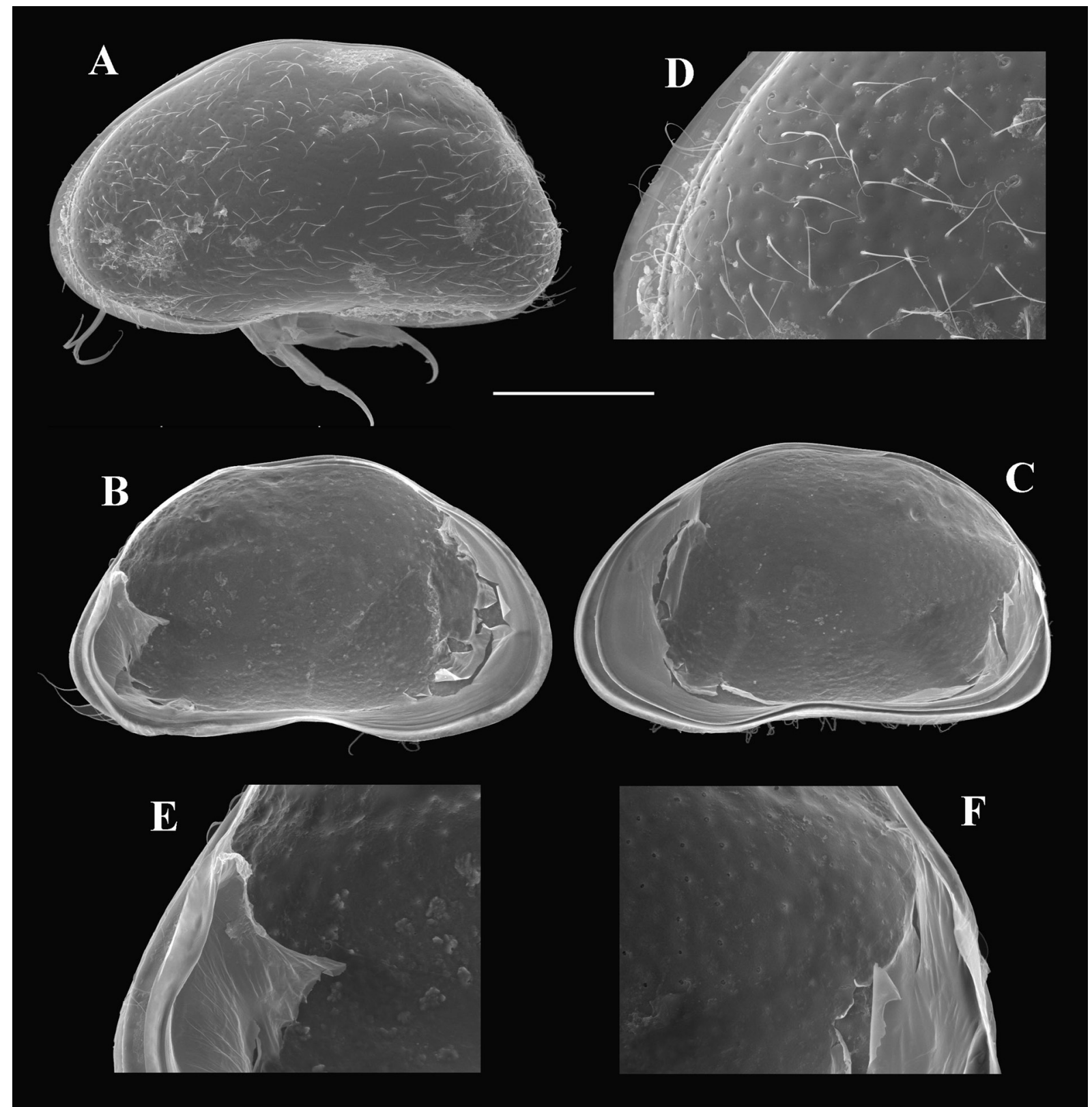

Fig. 15. Siamopsis planitia gen. et sp. nov., ๆ. A. CpL (MSU-ZOC.209). B. LVi (MSU-ZOC.207). C. RVi (idem). D. Valve surface of CpL (MSU-ZOC.209). E. Postero-dorsal part of LVi (MSU-ZOC.207). F. Postero-dorsal part of RVi (idem). Scale bar: A-C $=200 \mu \mathrm{m}$; D $=64 \mu \mathrm{m}$; E-F $=85 \mu \mathrm{m}$. 
T1 (Fig. 17C-D). Protopodite with two unequally short a-setae, b- and d-setae absent, distally with ca 10 hirsute apical setae of unequal length. Endopodite a weakly built palp, with one very long, hirsute and two unequally short apical setae.

T2 (Fig. 18A). With d2 seta (d1 absent). Second segment with short e-seta (reaching mid-length of penultimate segment). Penultimate segment divided, proximal segment bearing long f-seta (reaching

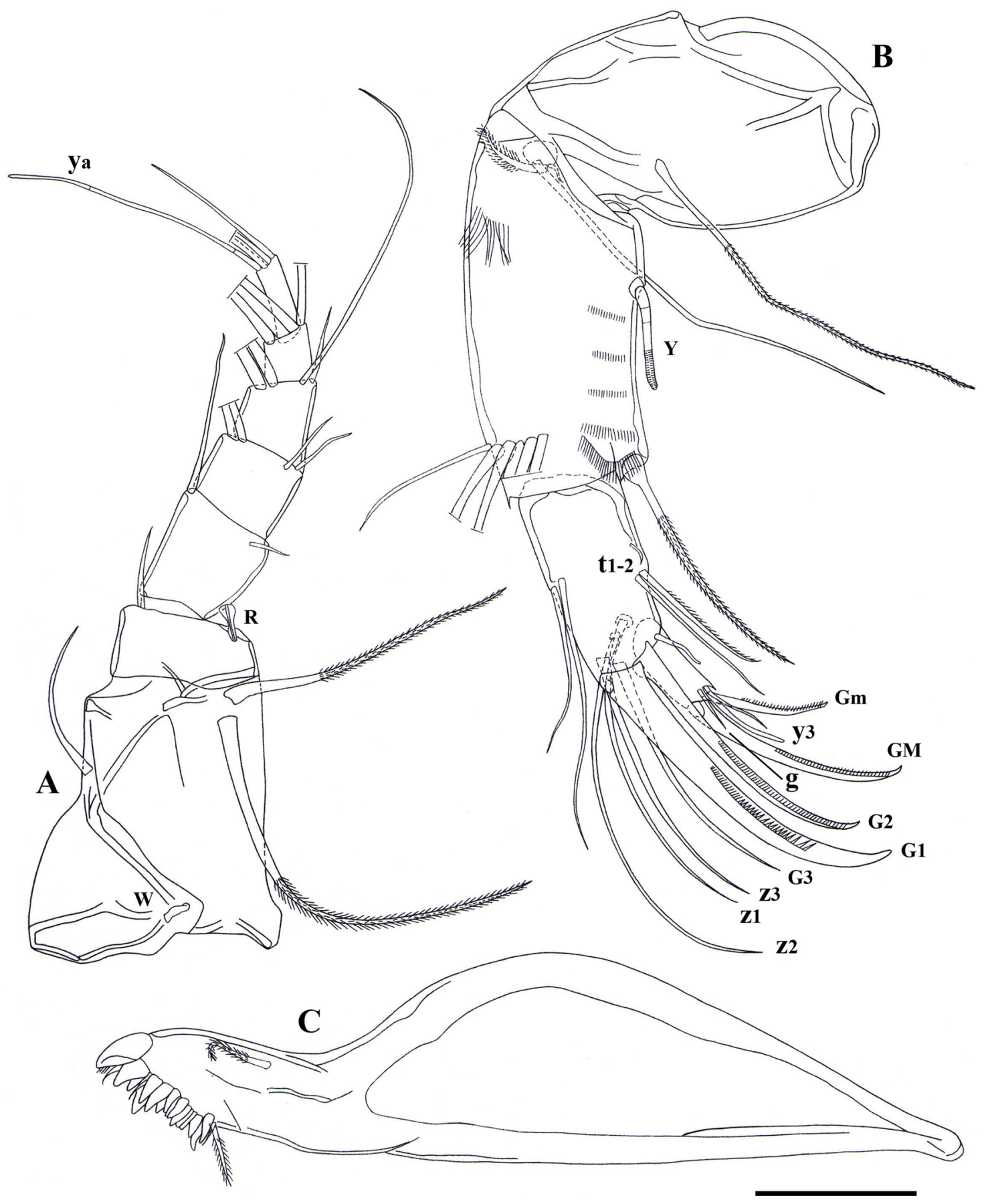

Fig. 16. Siamopsis planitia gen. et sp. nov., $q$ (MSU-ZOC.207). A. A1. B. A2. C. Md coxa. Scale bar: $50 \mu \mathrm{m}$. 
beyond tip of terminal segment), distal segment with pair of apical setae (long g-seta, one short), g-seta reaching tip of terminal segment. Terminal segment with two (one dorsally, one ventrally) apical hl and h3 setae (length of former ca $1 / 3$ that of claw, latter short) and serrated claw (h2), length of h2 longer than that of penultimate segment.

T3 (Fig. 18B). A cleaning limb. First segment with long d1, d2 and dp setae, d1 and d2 setae subequal in length. Second segment with long apical e-seta (reaching half length of next segment). Third segment

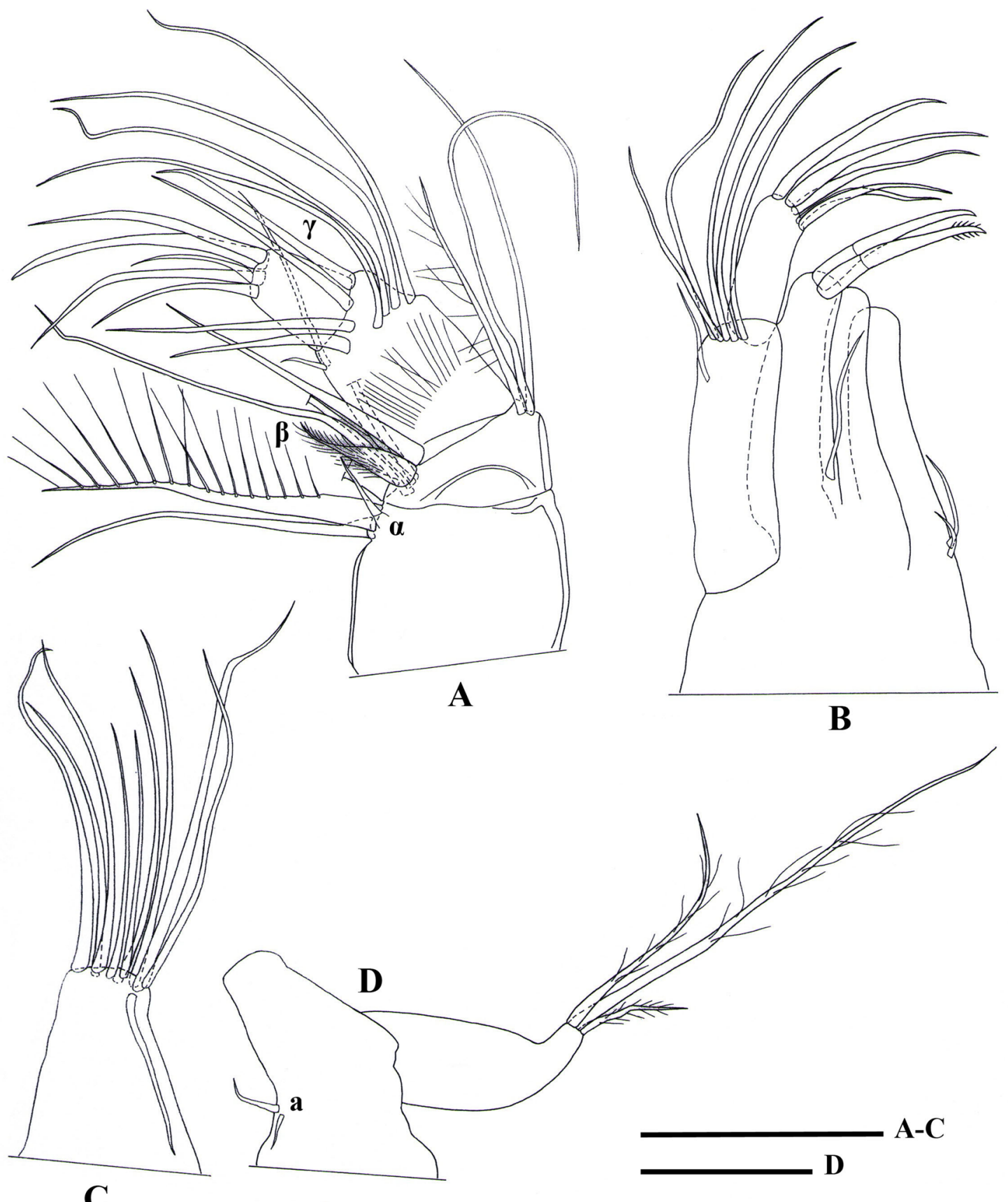

Fig. 17. Siamopsis planitia gen. et sp. nov., 9 (MSU-ZOC.207). A. Md palp. B. Mx1. C. T1, apical setae on protopodite. D. T1. Scale bars: $50 \mu \mathrm{m}$. 
with medially long f-seta (reaching tip of segment). Terminal segment with an apical pincer and one reflexed subapical seta, length of latter equal to that of third segment.

CR (Fig. 18C). Reduced, flagellum-like, cylindrical in shape, with a small lateral seta and long apical seta, length of latter ca 1.8 times that of ramus.

\section{Male}

Unknown.

\section{Ecology}

The new species has so far been recorded from five localities in Nakhon Ratchasima, Phetchabun and Chiang Mai Provinces. It occurs at a $\mathrm{pH}$ range of $6.50-7.38$, a temperature range of $24.2-29.3^{\circ} \mathrm{C}$ and a DO range of $3.20-8.14 \mathrm{mg} / \mathrm{l}$.

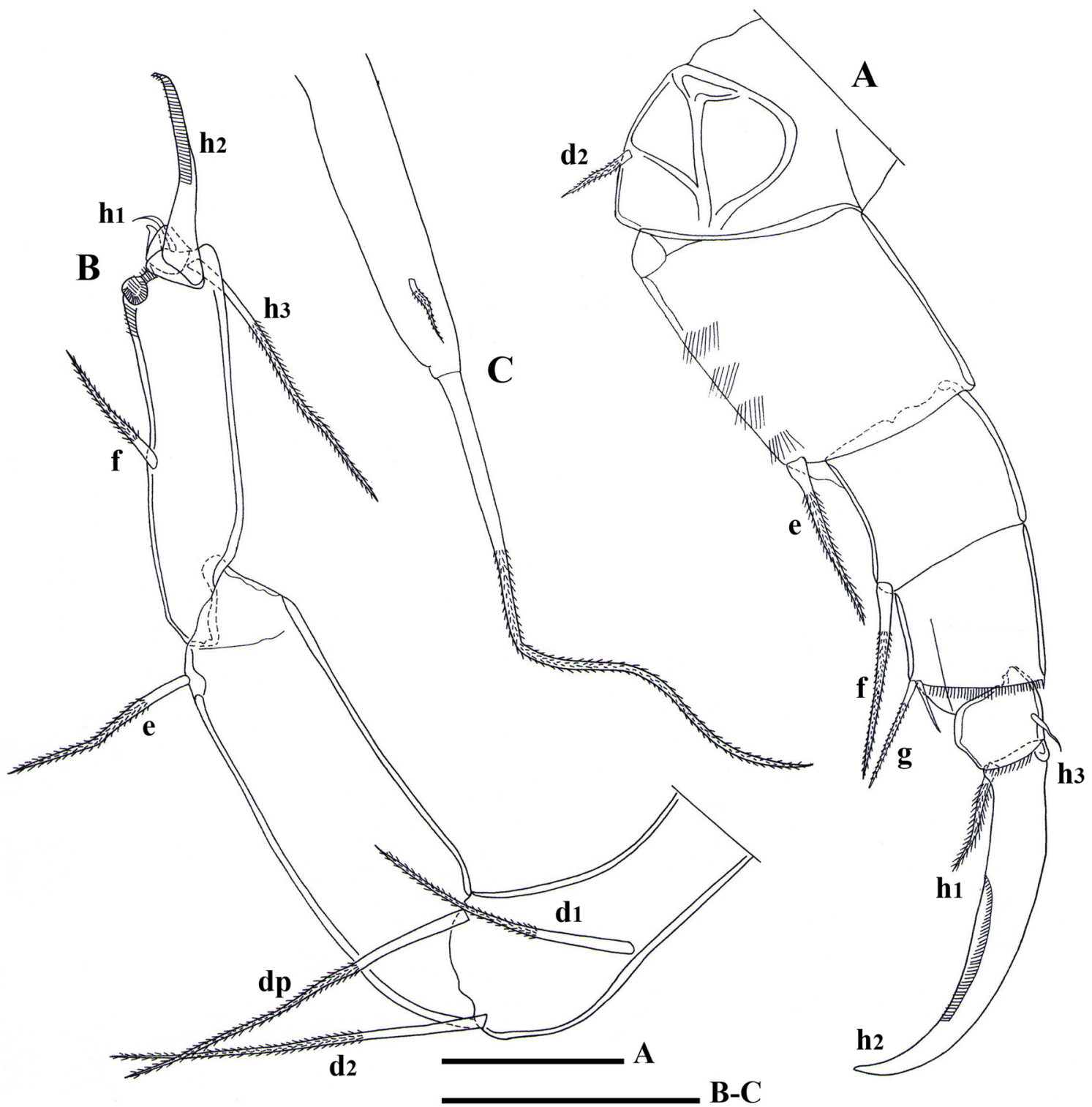

Fig. 18. Siamopsis planitia gen. et sp. nov., $q$ (MSU-ZOC.207). A. T2. B. T3. C. CR. Scale bars: $50 \mu \mathrm{m}$. 


\section{Key to species of Siamopsis gen. nov.}

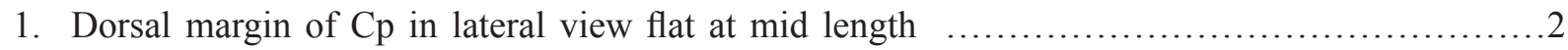

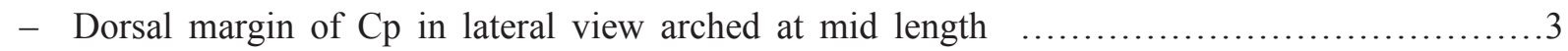

2. Postero-dorsal plate of LV in internal view broad, with a small tooth-like tubercle on anterior part, RV in internal view with tubercle-like structures under postero-ventral inner list

S. khoratensis gen. et sp. nov.

- Postero-dorsal plate of LV in internal view elongated, without tooth-like tubercle, RV in internal view without tubercle-like structures under postero-ventral inner list ...S. planitia gen. et sp. nov.

3. Cp in lateral view subtriangular, postero-dorsal plate of LV in internal view broad, with two small teeth-like tubercles on margin, RV in internal view without tubercle-like structures under postero-ventral inner list ..................................... renateae gen. et sp. nov.

- $\mathrm{Cp}$ in lateral view elongated, postero-dorsal plate of LV broad or elongated, RV in internal view with tubercle-like structures under postero-ventral inner list

4. Postero-dorsal plate of LV in internal view broad, with tooth-like tubercle in the middle S. conspecta gen. et sp. nov.

- Postero-dorsal plate of LV in internal view elongated, with tooth-like tubercle on posterior margin

S. suttajiti gen. et sp. nov.

\section{Key to genera with RV overlapping LV in the subfamily Cypridopsinae}

1. CR absent in both male and female ........................Martenscypridopsis Karanovic, 2000

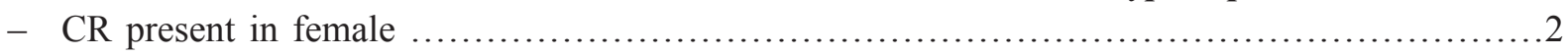

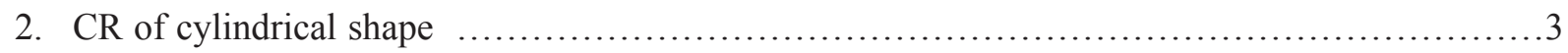

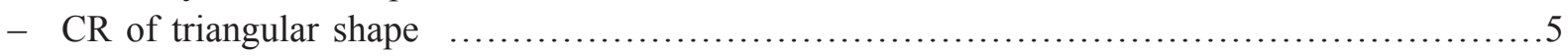

3. RV with well developed septa beneath posterior inner list

Klieopsis Martens et al., 1991

- RV without well developed septa beneath posterior inner list .............................

4. Internal LV with a plate-like protrusion on the postero-dorsal part, two t-setae on female A2 ...... ....Siamopsis gen. nov.

- Internal LV without a plate-like protrusion on the postero-dorsal part, four t-setae on female A2 ... Plesiocypridopsis Rome, 1965

5. Valves very elongated $(\mathrm{L} / \mathrm{H}>2)$, posterior selvage of internal $\mathrm{LV}$ displaced substantially to the front ... Tanganyikacypridopsis (Martens, 1985)

- Valves not very elongated $(\mathrm{L} / \mathrm{H}<2)$, posterior selvage of internal LV not displaced substantially to the front

Sarscypridopsis McKenzie, 1977

6. A2 natatory setae long, carapace subtriangular

7. RV without inner list, left prehensile palp with slender finger-like terminal segment, terminal segment of Mx1 palp with (slightly) enlarged tip .........Thermopsis Külköylüoğlu et al., 2003

- RV with inner list, left prehensile palp without slender finger-like terminal segment, terminal segment of Mx1 palp without enlarged tip 
8. Left prehensile palp with terminal segment enlarged distally, terminal segment of Mx1 palp very

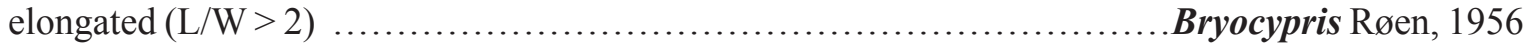

- Left prehensile palp without terminal segment enlarged distally, terminal segment of Mx1 palp not

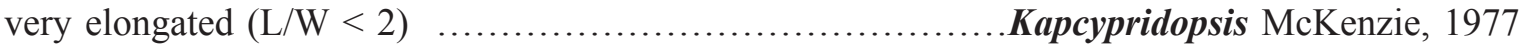

\section{Discussion}

The new genus is the sixth and third cypridopsine genus reported from the Oriental and Southeast Asian regions, respectively. The present study increases the total number of Southeast Asian cypridopsine species from six (Sars 1903; Victor \& Fernando 1981; Savatenalinton et al. 2008; Savatenalinton 2009, 2010; Tressler 1937) to 11. In the following, the affinities among genera of the subfamily Cypridopsinae and the morphological characters of the new genus are discussed.

Siamopsis gen. nov., described here, belongs to the group where the RV overlaps the LV. A key to genera with RV overlapping LV of the subfamily Cypridopsinae is given above. This group comprises nine genera: Martenscypridopsis Karanovic, 2000, Klieopsis Martens et al., 1991, Plesiocypridopsis Rome, 1965, Tanganyikacypridopsis Martens, 1985, Sarscypridopsis McKenzie, 1977, Kapcypridopsis McKenzie, 1977, Thermopsis Külköylüoğlu et al., 2003, Bryocypris Røen, 1956 and Siamopsis gen. nov. Among these genera, the occurrence of a cylindrical CR has been recognized in three genera, Klieopsis, Plesiocypridopsis and Siamopsis gen. nov. These three genera also share other features, e.g., the absence of the ventral apical seta on the Mx1 palp and of the d-seta on T1. The new genus can be distinguished from Plesiocypridopsis and Klieopsis by the presence of a plate-like protrusion on the postero-dorsal part of the internal LV, the morphology of the two large bristles on the Mx1 third endite, one being smooth and the other serrated (both bristles are serrated in Klieopsis and Plesiocypridopsis) and the presence of the Wouters organ on A1. Additionally, Siamopsis gen. nov. can be distinguished from Plesiocypridopsis by the number of t-setae on the female A2 penultimate segment (two in the new genus and four in Plesiocypridopsis) and the five apical setae on the terminal segment of the Mx1 palp (four in Plesiocypridopsis). Siamopsis gen. nov. differs from Klieopsis mainly in the presence of long natatory setae and the absence of a robust internal septa of the RV posterior inner list. The conspicuous morphology of the RV postero-ventral inner list of Klieopsis is the outstanding character that, so far, has not been observed in any other cypridopsine genera (Martens et al. 1991). However, a similar structure appears in three species of Siamopsis gen. nov. (S. suttajit gen. et sp. nov., S. conspecta gen. et sp. nov. and $S$. khoratensis gen. et sp. nov.). These species have a few tiny tubercle-like structures beneath the postero-ventral inner list of the RV (Fig. 19B-D). Due to their identical positions, this feature in the new genus could be the initiating form of the septa (it is in a well developed form in Klieopsis) and therefore shows the similarity between these two genera.

The Wouters organ on the first segment of the A1 appears in all five species of Siamopsis gen. nov. This is the first report of this organ in the subfamily Cypridopsinae. The length of the ya on the A1 terminal segment varies in different species. However, it was found that the ya was longer, but to different degrees, than the shortest seta of the terminal segment in Siamopsis gen. nov.

It is obvious that the natatory setae on $\mathrm{A} 2$ can be either longer or reduced to short setae (as in, e.g., Klieopsis, Thermopsis, Bryocypris and Cavernocypris Hartmann, 1964) in Cypridopsinae (see Meisch 2000; Karanovic 2012). The t-setae on the A2 penultimate segment are different in number between genders and between genera. Based on the occurrence of t-setae in females, there are two groups of genera: with four setae and with two setae. The former group comprises, e.g., Plesiocypridopsis (see Meisch 2000), Thermopsis (see Külköylüoğlu et al. 2003), Bryocypris (see Martens 1989), Tanganyikacypridopsis (see Martens 1985), Cypridopsis (see Meisch 2000), Potamocypris Brady, 1870 (see Meisch 2000; Horne \& Smith 2004) and Cabelodopsis (see Higuti \& Martens 2012), whereas the latter group, with two t-setae in the females, is represented by, for example, Sarscypridopsis (De Deckker 1981; Meisch 
2000; Dumont \& Martens 1996), Klieopsis (Martens et al. 1991) and Siamopsis gen. nov. In males, only one pattern (two t-setae) has so far been recognized (De Deckker 1981; Martens \& Meisch 1985; Martens 1989; Martens et al. 1991; Dumont \& Martens 1996; Meisch 2000; Külköylüoğlu et al. 2003). Thus, the number of t-setae is a sexual feature in some cypridopsine genera, such as Thermopsis and Bryocypris, in which it is reduced in males.

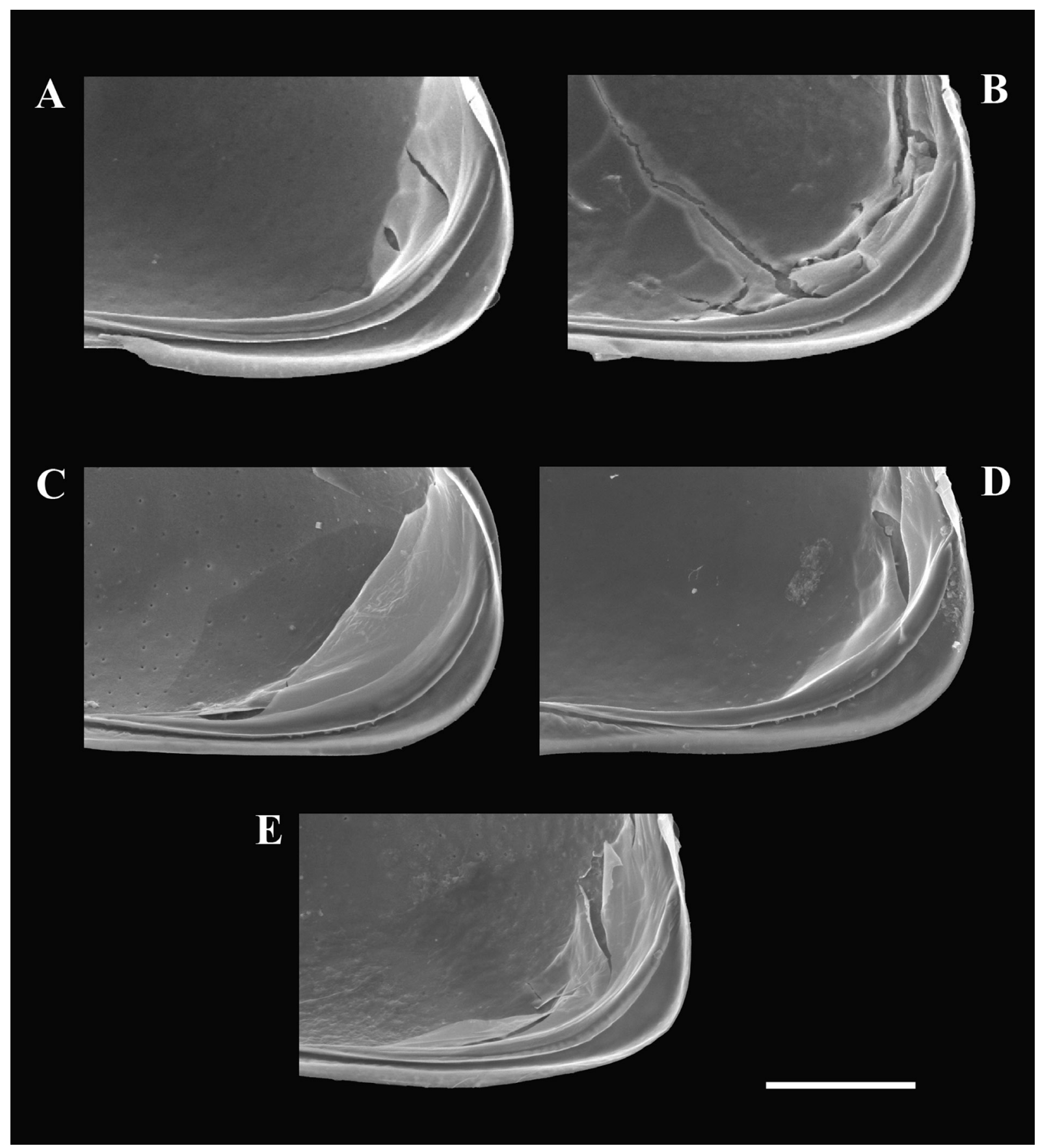

Fig. 19. Postero-ventral part of internal RV in Siamopsis spp., showing a smooth inner list and a few tiny tubercle-like structures beneath the inner list. A. S. renateae gen. et sp. nov. B. S. conspecta gen. et sp. nov. C. S. suttajit gen. et sp. nov. D. S. khoratensis gen. et sp. nov. E. S. planitia gen. et sp. nov. Scale bar: $100 \mu \mathrm{m}$. Arrows indicate tiny tubercle-like structures under postero-ventral inner list. 
The Md palp is normally developed in the subfamily Cypridopsinae. However, in the new genus, the morphology of the ventro-apical seta on the penultimate segment is similar to that of the $\gamma$-seta, showing a plumose and long seta.

The shape of the terminal segment of the Mx1 palp can be divided into two groups: spatulate and cylindrical shapes. While most of the cypridopsine genera have cylindrical terminal segments, the spatula shape occurs in Potamocypris only (see Meisch 2000; Karanovic 2012). Other features of this limb can also be used as generic characters of the subfamily, for example, the occurrence of a ventro-subapical seta on the basal segment of the palp. This seta is absent in, e.g., Siamopsis gen. nov., Plesiocypridopsis and Klieopsis.

The occurrence of $\mathrm{a}, \mathrm{b}, \mathrm{c}$ and $\mathrm{d}$ setae on the $\mathrm{T} 1 \mathrm{~h}$ has been used as a diagnostic feature in several subfamilies. For example, the presence of the c-seta is a distinguishing aspect of the subfamily Eucypridinae (Meisch 2000) and the presence of the d-seta distinguishes Strandesia Stuhlmann, 1888 from Pseudostrandesia Savatenalinton \& Martens, 2008 in subfamily Cypricercinae (see Savatenalinton 2009). In the subfamily Cypridopsinae, the presence of only two a-setae is a fundamental pattern in all genera, including Siamopsis gen. nov., while the d-seta has only been seen in Cabelodopsis (Higuti \& Martens 2012).

The occurrence of the $\mathrm{T} 2 \mathrm{~d}$-setae is one of the generic characters of several subfamilies. Both setae appear in almost all subfamilies of the Cyprididae and Candonidae, except for, e.g., subfamily Cyclocypridinae, in which d1 is present in, e.g., Allocypria Rome, 1962, Cyclocypris Brady \& Norman, 1889 and Kempfcyclocypris Karanovic, 2011, but absent in, e.g., Cypria Zenker, 1854, Keysercypria Karanovic, 2011 and Dentocypria Savatenalinton, 2017 (see Meisch 2000; Karanovic 2012; Savatenalinton 2017). In Cypridopsinae, only the $\mathrm{d} 2$ seta is present ( $\mathrm{d} 1$ absent) in all genera. Thus, this character should be mentioned in the diagnosis of the subfamily.

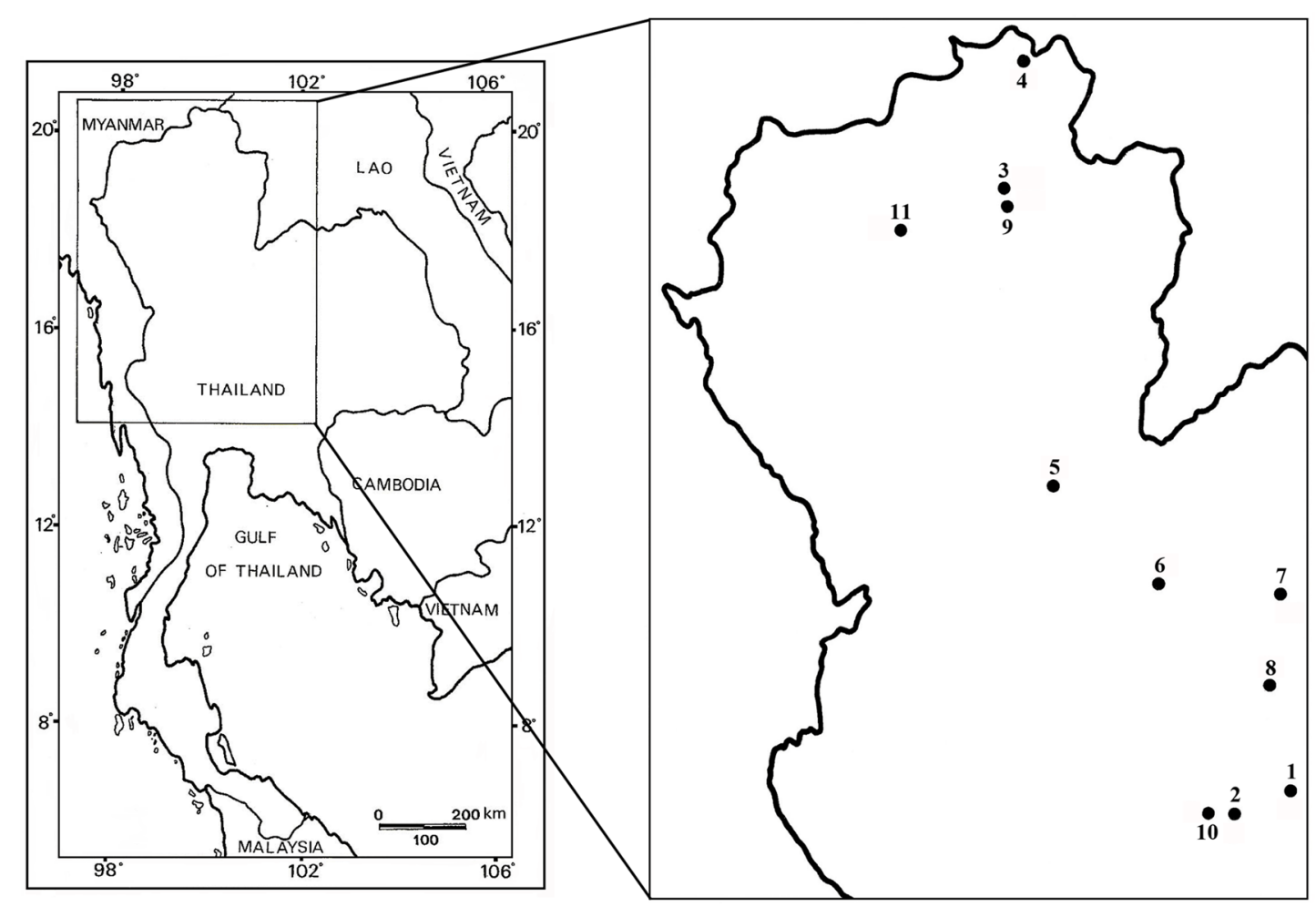

Fig. 20. Sampling localities of species of Siamopsis gen. nov. (for information on locality numbers, see the text). 
Although the valve overlap and the shapes of the CR and the terminal segment of the Mx1 palp are the most important diagnostic features (Meisch 2000; Karanovic 2012), there are still many distinguishing characters between the genera of the subfamily Cypridopsinae. The phylogeny of the subfamily, based on morphological characters, including a discussion of generic characters, will be presented elsewhere.

\section{Acknowledgements}

This study was supported by Mahasarakham University, Thailand (contract number 5705022/2557). The presentation of this research at the $8^{\text {th }}$ European Ostracodologists' Meeting (EOM8) in Estonia was financially supported by the Mahasarakham University Development Fund and the Faculty of Science, Mahasarakham University, Thailand. Two anonymous reviewers are thanked for their useful comments. Prof. Koen Martens (RBINS, Brussels) is acknowledged for suggestions. Julien Cillis (RBINS, Brussels) and Nual-arnong Nakkong (Mahasarakham University, Thailand) offered technical assistance with the scanning electron micrographs. Chaiburin Savatenalinton is thanked for field assistance. Dr. Jolyon Dodgson (Mahasarakham University, Thailand) helped with the correction of the English.

\section{References}

Broodbakker N.W. \& Danielopol D.L. 1982. The chaetotaxy of Cypridacea (Crustacea, Ostracoda) limbs: proposals for a descriptive model. Bijdragen tot de Dierkunde 52 (2): 103-120.

De Deckker P. 1981. Ostracoda from Australian inland waters - Notes on taxonomy and ecology. Proceedings of the Royal Society of Victoria 93 (1): 43-85.

Dumont H. \& Martens K. 1996. The freshwater microcrustacea of Easter Island. Hydrobiologia 325: 83-99. https://doi.org/10.1007/BF00028269

Hartmann G. 1964. Asiatische Ostracoden. Systematische und zoogeographische Untersuchungen. Internationale Revue der gesamten Hydrobiologie, Systematische Beihefte 3: 1-155.

Higuti J. \& Martens K. 2012. On a new cypridopsine genus (Crustacea, Ostracoda, Cyprididae) from the Upper Paraná River floodplain (Brazil). Zootaxa 3391: 23-38.

Horne D.J. \& Smith R.J. 2004. First British record of Potamocypris humilis (Sars, 1924), a freshwater ostracod with a disjunct distribution in Europe and Southern Africa. Bollettino della Società Paleontologica Italiana 43 (1-2): 297-306.

Karanovic I. 2012. Recent Freshwater Ostracods of the World: Crustacea, Ostracoda, Podocopida. Springer-Verlag, Berlin and Heidelberg. https://doi.org/10.1007/978-3-642-21810-1

Külköylüoğlu O., Meisch C. \& Rust R.W. 2003. Thermopsis thermophila n. gen. n. sp. from hot springs in Nevada, U.S.A. (Crustacea, Ostracoda). Hydrobiologia 499: 113-123.

https://doi.org/10.1023/A:1026308514466

Martens K. 1985. Tanganyikacypridopsis gen. n. (Crustacea, Ostracoda) from Lake Tanganyika. Zoologica Scripta 14 (3): 221-230.

Martens K. 1987. Homology and functional morphology of the sexual dimorphism in the antenna of Sclerocypris Sars, 1924 (Crustacea, Ostracoda, Megalocypridinae). Bijdragen tot de Dierkunde 57 (2): 183-190.

Martens K. 1989. On Bryocypris grandipes Røen. Stereo-Atlas of Ostracod Shells 16 (29): 140-147.

Martens K. \& Meisch C. 1985. Description of the male of Potamocypris villosa (Jurine, 1820) (Crustacea, Ostracoda). Hydrobiologia 127: 9-15. https://doi.org/10.1007/BF00004658

Martens K. \& Savatenalinton S. 2011. A subjective checklist of the Recent, free-living, non-marine Ostracoda (Crustacea). Zootaxa 2855: 1-79. 
Martens K., Meisch C. \& Marmonier P. 1991. On Klieopsis n. gen., with a redescription of Cypridpsis horai Klie, 1927 (Crustacea, Ostracoda). Bulletin van het Koninklijk Belgisch Instituut voor Natuurwetenschappen, Biologie 61: 55-64.

Meisch C. 2000. Freshwater Ostracoda of Western and Central Europe. In: Schwoerbel J. \& Zwick P. (eds) Süßwasserfauna von Mitteleuropa 8 (3): 1-522. Spektrum Akademischer Verlag, Heidelberg and Berlin.

Sars G.O. 1903 Freshwater Entomostraca from China and Sumatra. Archiv for Mathematik og Naturvidenskab 25: 3-44.

Savatenalinton S. 2015. On three new species of non-marine ostracods (Crustacea: Ostracoda) from Northeast Thailand. Zootaxa 3914 (3): 275-300. https://doi.org/10.11646/zootaxa.3914.3.3

Savatenalinton S. 2017. A new genus and four new species of subfamily Cyclocypridinae (Crustacea, Ostracoda) from Thailand. Zootaxa 4243 (2): 329-365. https://doi.org/10.11646/zootaxa.4243.2.4

Savatenalinton S. \& Martens K. 2009. Generic revision of Cypricercinae McKenzie, 1971 (Crustacea, Ostracoda), with description of three new genera and one new species and phylogenetic analysis of the subfamily. Hydrobiologia 632 (1): 1-48. https://doi.org/10.1007/s10750-009-9826-5

Savatenalinton S. \& Martens K. 2010. On the subfamily Cypricercinae McKenzie, 1971 (Crustacea, Ostracoda) from Thailand, with the description of six new species. Zootaxa 2379: 1-77.

Savatenalinton S. \& Suttajit M. 2016. A checklist of recent non-marine ostracods (Crustacea: Ostracoda) from Thailand, including descriptions of two new species. Zootaxa 4067 (1): 1-34.

https://doi.org/10.11646/zootaxa.4067.1.1

Savatenalinton S., Borgonie G. \& Martens K. 2008. On Thaicythere srisumonae n. gen., n. sp. (Ostracoda) from Thailand, with notes on the phylogeny of the subfamily Timiriaseviinae Mandelstam, 1960. Crustaceana 81: 411-432. https://doi.org/10.1163/156854008783797543

Tressler W.L. 1937. Ostracoda. Mitteilung 18 von der Wallacea-Expedition Woltereck 1931-32. Internationale Revue der Gesamten Hydrobiologie und Hydrographie 34 (3-5): 188-207.

Victor R. \& Fernando C.H. 1981. An Illustrated Key to the Freshwater Ostracod Genera of the Oriental Region. Department of Biology, University of Waterloo, Canada.

Manuscript received: 14 February 2017

Manuscript accepted: 16 June 2017

Published on: 19 December 2017

Topic editor: Rudy Jocqué

Desk editor: Kristiaan Hoedemakers

Printed versions of all papers are also deposited in the libraries of the institutes that are members of the EJT consortium: Muséum national d'Histoire naturelle, Paris, France; Botanic Garden Meise, Belgium; Royal Museum for Central Africa, Tervuren, Belgium; Natural History Museum, London, United Kingdom; Royal Belgian Institute of Natural Sciences, Brussels, Belgium; Natural History Museum of Denmark, Copenhagen, Denmark; Naturalis Biodiversity Center, Leiden, the Netherlands; Museo Nacional de Ciencias Naturales-CSIC, Madrid, Spain; Real Jardín Botánico de Madrid CSIC, Spain. 